\title{
Geologic Processes in the RWMC Area, Idaho National Engineering Laboratory: Implications for Long Term Stability and Soil Erosion at the Radioactive Waste Management Complex
}

\author{
W. R. Hackett \\ J. A. Tullis \\ R. P. Smith \\ S. J. Miller \\ T. V. Dechert* \\ P. A. McDaniel* \\ A. L. Falen*
}

September 1995

Idaho National Engineering Laboratory

Lockheed Martin Idaho Technologies

Idaho Falls, Idaho 83415

\author{
and \\ University of Idaho \\ College of Agriculture \\ Soil Science Division \\ Moscow, Idaho 83844-2339 \\ Prepared for the \\ U.S. Department of Energy \\ Assistant Secretary for Environmental Management \\ Under DOE Idaho Operations Office \\ Contract DE-AC07-94ID13223
}




\section{DISCLAIMER}

This report was prepared as an account of work sponsored by an agency of the United States Government. Neither the United States Government nor any agency thereof, nor any of their employees, make any warranty, express or implied, or assumes any legal liability or responsibility for the accuracy, completeness, or usefulness of any information, apparatus, product, or process disclosed, or represents that its use would not infringe privately owned rights. Reference herein to any specific commercial product, process, or service by trade name, trademark, manufacturer, or otherwise does not necessarily constitute or imply its endorsement, recommendation, or favoring by the United States Government or any agency thereof. The views and opinions of authors expressed herein do not necessarily state or reflect those of the United States Government or any agency thereof. 


\section{DISCLAIMER}

Portions of this document may be illegible in electronic image products. Images are produced from the best available original document. 


\section{EXECUTIVE SUMMARY}

Since 1952, radioactive waste has been disposed by shallow-land burial at the Radioactive Waste Management Complex (RWMC) at the Idaho National Engineering Laboratory (INEL). The RWMC is a disposal facility for radioactive waste, located in a small $\left(2.6 \mathrm{~km}^{2}\right)$ shallow basin in the southwest portion of the INEL. It is anticipated that waste disposal will continue for at least another decade. Prior to 1970, disposed waste included transuranic waste and low-level radioactive waste, sometimes mixed with EPA hazardous waste; since 1970, however, the waste placed in disposal there has been restricted to low-level waste.

Current practice at the RWMC is to cover disposed waste with a layer of soil at least $2 \mathrm{~m}$ thick for isolation. The intent is that by the time waste disposal at the RWMC is terminated, all disposed waste will have been placed beneath a cover of at least this thickness, and prospectively by an additional engineered barrier that is not yet designed.

Since some radionuclides in the waste placed in disposal at the RWMC have radioactive halflives sufficiently long to require limited release rates for hundreds of years, it is important that their isolation barrier (including the soil layer covering them) endure sufficiently long to restrict radionuclide release rates to acceptable levels. Any eventuality that could reduce the effectiveness of the waste isolation barrier requires evaluation and appropriate actions to ensure adequate barrier performance.

Natural erosion of the soil cover over the waste is one process by which the isolation of the waste could be reduced. The purpose of investigations covered by this report is to evaluate the prospects for reduction or loss of the cover over the disposed waste due to natural causes.

The time period selected in this assessment of future soil erosion and geologic stability at the RWMC extends from the present to the future 10,000 years. This period was selected for reasons of regulatory compliance and geological interpretation and projection.

In order to evaluate these prospects, investigations have addressed the many geologic processes that have, through millions of years, affected the Southeast Idaho region and the specific location of the RWMC on the Eastern Snake River Plain. These include lithospheric processes (tectonic, seismic, volcanic) and surficial geomorphic processes (flooding, weathering, soil formation, glacial episodes, etc.). The RWMC is located in a temperate climate in an approximately 1 -mi-high valley that is surrounded by basin-and-range mountains. The region has been greatly affected by slow movement ( 3 to $4 \mathrm{~cm} / \mathrm{yr}$ ) of the North American tectonic plate relative to a hot spot in the earth's mantle. (This hot spot was beneath the INEL area 4.0 to 6.5 million years ago, but now underlies Yellowstone National Park). The present landforms owe much of their origin to basaltic volcanism, coupled with sedimentation related to past glacial climates.

The past 10,000 years (i.e., the Holocene period, which follows the last glacial period) was a period of soil formation and limited erosion in the small valley in which the RWMC is located; there appears to be a good prospect that this situation (of essentially no erosion) will continue at least until the next glacial period. 
The annual probability of recurrence of tectonic surface faulting and volcanism is not greater than $5 \times 10^{-4}$ to $1 \times 10^{-5}$. Additionally, the annual probability of earthquake ground motion of $0.3 \mathrm{~g}$ is below $1 \times 10^{-5}$, and such motion would not tend to decrease the cover or disrupt the waste. (It could cause breakage of badly deteriorated containers.)

With regard to surficial geomorphic processes, the following processes that might affect the thickness of the cover were considered, with findings or conclusions summarized as noted:

1. Long-term (starting over 4 million years ago) and continuing subsidence (approximately $0.3 \mathrm{~mm} / \mathrm{yr}$ ) of the ESRP. This has resulted in continued accumulation (on the ESRP) of materials eroded from the surrounding mountains, and will continue far beyond the next 10,000 years. This subsidence of the ESRP will tend to increase the thickness of the soil accumulation on the ESRP, including the RWMC basin - not erode it.

2. Weathering and soil formation processes. These affect only the sediments already in place and do not contribute to or decrease the amount of fill on the basin floor.

3. Slope wash and soil creep. These processes have moved and will continue to move surficial sediments off the slopes surrounding the RWMC and into the bottom of the basin (where the RWMC is located), thereby tending to add to the soil thickness there.

4. Catastrophic slope failure (landsliding). This is an insignificant prospect at the RWMC because of the low topographic relief and small slope angles in the vicinity of the RWMC. Moreover, if such a process were to occur, it would have an effect similar to that in number 3 above.

5. Unusual precipitation events and/or rapid snowmelt while the ground is frozen has lead to local basin flooding. Such flooding has been observed several times in the RWMC's history, and no doubt has occurred a great many times. The effect of each such flooding is to inundate the bottom of the basin for days or weeks. Partly because such floodings have caused low-density disposed waste packages to float to the surface, perimeter earthberms have been constructed around the RWMC. Those will prevent such flooding through the period of institutional control, provided they are maintained. For protection beyond the period of institutional control, actions are needed to ensure that the density of the disposed waste is greater than the soil, i.e., $>120 \mathrm{lb} / \mathrm{ft} \#$; this can be achieved through waste management actions. Basin outflow along the natural channel to the Big Lost River may remove some floodwaters from the basin. No specific evidence has been observed of sediment transport out of the basin along the channel, and it appears that outflow from local basin flooding events does not have sufficient discharge or velocity for sediment transport. However, if these events had a sufficient magnitude, duration, and frequency to transport sediment, they could cause headward erosion into the basin sediments, thus causing removal.

6. Regional tributary floods. These have caused water to enter the RWMC basin on a number of occasions in Holocene time through the wind gaps in the adjacent Quaking Aspen Butte basalt flow, and have left a thin scattering of small $(<2 \mathrm{~mm})$ alluvial gravels on the surface just inside the basin near the wind gaps. Engineered flood control dikes 
can protect the RWMC area through the period of institutional control (100 years after RWMC closure) at which time the dikes will begin loss of integrity due to natural erosive processes. While such loss of integrity will allow flooding of the RWMC, the floodwater velocities are likely to be so low that erosion of only a few centimeters is likely to occur.

7. Glacial outburst flooding. Such flooding inundated the RWMC during the Late-Pinedale glaciation (about 20,000 years ago), eroding sediments from higher convex positions around the basin and depositing large basalt boulders within the basin. Nevertheless, substantial soil layers having ages ranging from about 20,000 to 120,000 years remain apparently undisturbed, indicating that significant erosion of older soils did not occur.

8. Eolian processes. These have been important in the deposition of up to $100 \mathrm{~cm}$ of loess in the RWMC basin during the last glaciation. During the ensuing 10,000 years, the uppermost portion of the soil has evidently been little affected, varying in thickness by only a few centimeters as indicated by the small depth range within which all archaeological materials have been found. During this period, variations in climatic conditions have apparently had little effect on soil thickness.

9. Climate change influences on landscape stability. As mentioned in number 8 above, climate changes during the approximately 10,000 years subsequent to the last glaciation have had little effect on the soil landscape within the RWMC basin, and so it appears that if climate fluctuations are within historical limits the same may be true for the next 10,000 years. However, no attempt has been made here to predict the amount of temperature rise ultimately due to (for example) the "Greenhouse Effect", nor to attempt to predict the extremes of resultant wind velocities or atmospheric moisture. The world-wide impacts of extremes that might be sufficient to significantly affect the soil depth in the RWMC basin would likely greatly overshadow concern for a soil depth change there.

In conclusion, the effects of the above discussed processes (which include all natural processes. considered to be of probable significance) are of a magnitude and duration judged to be compatible with a projection that the soil landscape within the basin in which the RWMC is located will not be eroded beyond $50 \mathrm{~cm}$ below the existing natural landscape, until such time as climatic and temperature ranges typical of the last 10,000 years are exceeded.

\title{
DISCLAIMER
}

\begin{abstract}
This report was prepared as an account of work sponsored by an agency of the United States Government. Neither the United States Government nor any agency thereof, nor any of their employees, makes any warranty, express or implied, or assumes any legal liability or responsibility for the accuracy, completeness, or usefulness of any information, apparatus, product, or process disclosed, or represents that its use would not infringe privately owned rights. Reference herein to any specific commercial product, process, or service by trade name, trademark, manufacturer, or otherwise does not necessarily constitute or imply its endorsement, recommendation, or favoring by the United States Government or any agency thereof. The views and opinions of authors expressed herein do not necessarily state or reflect those of the United States Government or any agency thereof.
\end{abstract}




\section{CONTENTS}

EXECUTIVE SUMMARY $\ldots \ldots \ldots \ldots \ldots \ldots \ldots \ldots \ldots \ldots \ldots \ldots \ldots \ldots \ldots \ldots \ldots \ldots$ iii

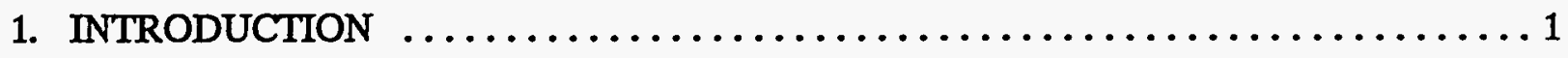

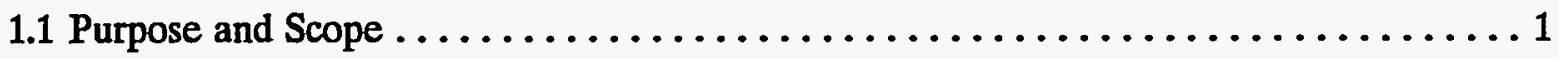

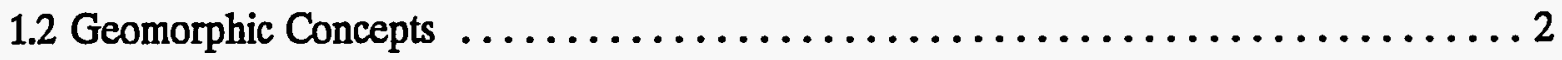

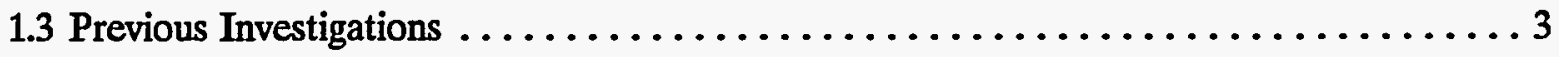

2. GEOLOGIC AND CLIMATOLOGIC PROCESSES IMPORTANT TO RWMC LAND SURFACE STABILITY $\ldots \ldots \ldots \ldots \ldots \ldots \ldots \ldots \ldots \ldots \ldots \ldots \ldots \ldots \ldots$

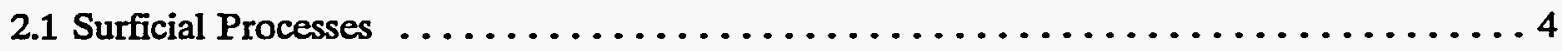

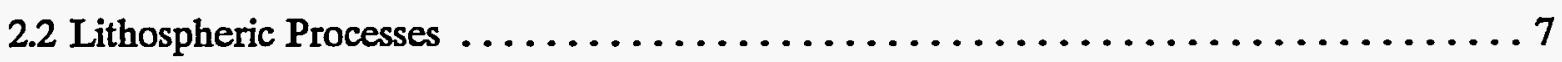

3. REGIONAL PHYSIOGRAPHY AND GEOLOGY $\ldots \ldots \ldots \ldots \ldots \ldots \ldots \ldots \ldots$

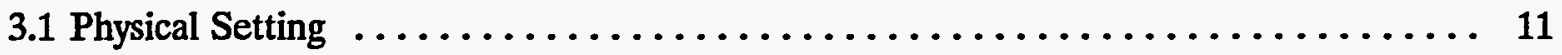

3.2 Geologic Processes and ESRP Landscape Evolution $\ldots \ldots \ldots \ldots \ldots \ldots \ldots \ldots$

4. RWMC PHYSIOGRAPHY AND GEOLOGY $\ldots \ldots \ldots \ldots \ldots \ldots \ldots \ldots \ldots \ldots \ldots \ldots \ldots \ldots \ldots$

4.1 Topographic Setting $\ldots \ldots \ldots \ldots \ldots \ldots \ldots \ldots \ldots \ldots \ldots \ldots \ldots \ldots \ldots \ldots \ldots \ldots \ldots \ldots \ldots \ldots \ldots, 22$

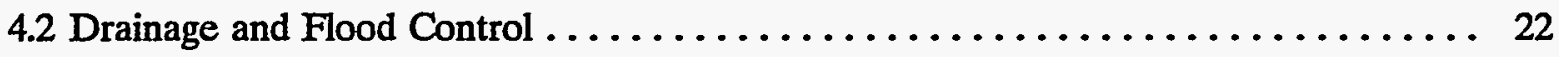

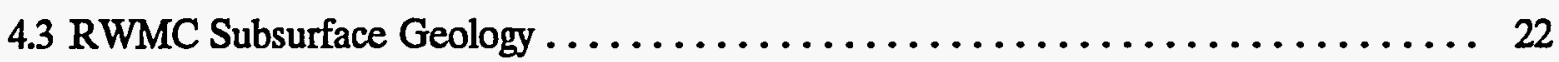

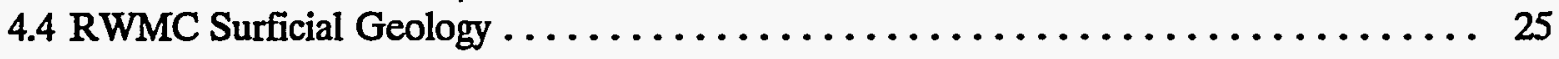

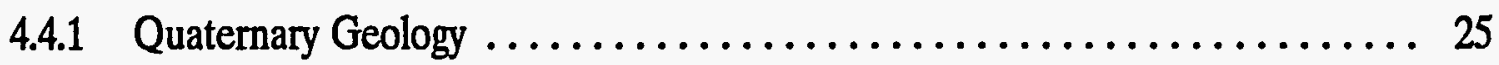

4.4.2 Quaternary Stratigraphy $\ldots \ldots \ldots \ldots \ldots \ldots \ldots \ldots \ldots \ldots \ldots \ldots \ldots \ldots \ldots \ldots \ldots \ldots \ldots, 32$

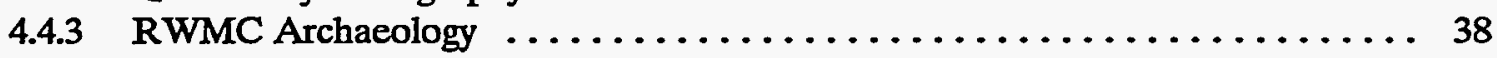

5. SUMMARY AND CONCLUSIONS $\ldots \ldots \ldots \ldots \ldots \ldots \ldots \ldots \ldots \ldots \ldots \ldots \ldots \ldots \ldots \ldots \ldots$

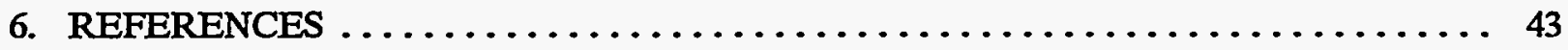

Appendix A-Glossary of Terms $\ldots \ldots \ldots \ldots \ldots \ldots \ldots \ldots \ldots \ldots \ldots \ldots \ldots \ldots \ldots \ldots \ldots \ldots \ldots \ldots \ldots$ 


\section{FIGURES}

1. Summary diagram of important ESRP geologic processes or events, and their estimated range of annual recurrence probabilities (hatchered bars) $\ldots \ldots \ldots \ldots \ldots \ldots \ldots \ldots$

2. Glacial/interglacial temperature fluctuations $\ldots \ldots \ldots \ldots \ldots \ldots \ldots \ldots \ldots \ldots \ldots$

3. Computer-generated, digital-topographic map of the INEL region $\ldots \ldots \ldots \ldots \ldots \ldots$

4. Generalized topographic and drainage map of the INEL area $\ldots \ldots \ldots \ldots \ldots \ldots$

5. Positions and ages of silicic volcanic centers associated with passage of the Yellowstone

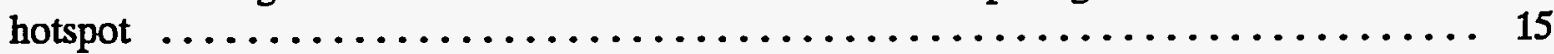

6. Holocene lava fields, volcanic-rift zones, and axial volcanic zone of the ESRP $\ldots \ldots \ldots$. 17

7. Generalized geologic map of the INEL area, showing the distribution of major basalt lavaflow groups and sedimentary deposits $\ldots \ldots \ldots \ldots \ldots \ldots \ldots \ldots \ldots \ldots \ldots \ldots$

8. Topographic map of the RWMC area $\ldots \ldots \ldots \ldots \ldots \ldots \ldots \ldots \ldots \ldots \ldots$

9. 1989 file photo of the RWMC area $\ldots \ldots \ldots \ldots \ldots \ldots \ldots \ldots \ldots \ldots \ldots \ldots \ldots$

10. Geologic map of $\mathrm{RWMC}$ and surrounding areas $\ldots \ldots \ldots \ldots \ldots \ldots \ldots \ldots \ldots$

11. Stratigraphic cross section of subsurface basaltic lava-flow groups and sedimentary

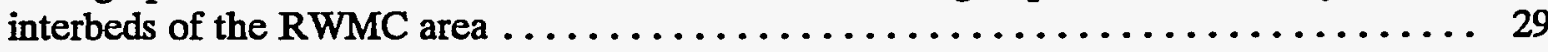

12. Depths and ages of lava flows in INEL boreholes $\ldots \ldots \ldots \ldots \ldots \ldots \ldots \ldots \ldots$

13. Stratigraphy, age estimates, particle-size distribution, and carbonate content of loess and basaltic lava flows exposed in the west wall of an $\mathrm{RWMC}$ open pit ........... 33

14. Stratigraphy, age estimates, particle-size distribution, and carbonate content of loess at site in the spreading areas, $1.5 \mathrm{~km}$ southeast of the $\mathrm{RWMC} \ldots \ldots \ldots \ldots \ldots \ldots \ldots$

15. Index map of the RWMC basin, showing the locations of selected soil sites $\ldots \ldots \ldots \ldots$

16. Soil profiles and stratigraphic relations between soil sites of the RWMC basin ...... 37

\section{TABLES}

1. Estimated volcanic-recurrence intervals for volcanic zones and borehole sites of the

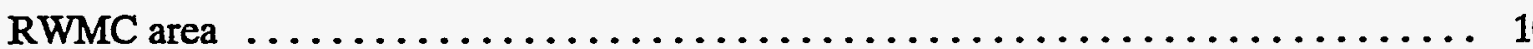

2. Late Pleistocene-Holocene climate and chronology of the ESRP and vicinity . . . . . . 19

3. Implications of erosional processes at the RWMC for the next $10^{4}$ years $\ldots \ldots \ldots \ldots 1$ 


\section{Geologic Processes in the RWMC Area, Idaho National Engineering Laboratory: Implications for Soil Erosion at the Radioactive Waste Management Complex}

\section{INTRODUCTION}

The Radioactive Waste Management Complex (RWMC) is the disposal and storage facility for low-level radioactive waste at the Idaho National Engineering Laboratory (INEL). Transuranic waste and mixed wastes were also disposed at the RWMC until 1970. It is located in the southwestern part of the INEL about $80 \mathrm{~km}$ west of Idaho Falls, Idaho. The INEL occupies a portion of the Eastern Snake River Plain (ESRP), a low-relief, basalt, and sediment-floored basin within the northern Rocky Mountains and northeastern Basin and Range Province. It is a cool and semiarid, sagebrush steppe desert characterized by irregular, rolling terrain.

The RWMC began disposal of INEL-generated wastes in 1952, and since 1954, wastes have been accepted from other Federal facilities. Much of the waste is buried in shallow trenches, pits, and soil vaults. Until about 1970, trenches and pits were excavated to the basalt surface, leaving no sediments between the waste and the top of the basalt. Since 1970, a layer of sediment (about $1 \mathrm{~m}$ ) has been left between the waste and the basalt.

The United States Department of Energy (DOE) has developed regulations specific to radioactive-waste disposal, including environmental standards and performance objectives. The regulation applicable to all DOE facilities is DOE Order 5820.2A (Radioactive Waste Management). The facility performance assessment quantitatively evaluates the ability of the disposal system to contain and isolate radioactive waste within the limits set by the regulations (Campbell and Cranwell, 1988). The facility performance assessment must (a) identify the physical processes and events that could cause the release of radioactive wastes to the environment, and (b) calculate probabilistic estimates of the likelihood of each process and/or event leading to a radioactive release.

An important consideration for the performance assessment of the RWMC is the long-term geomorphic stability of the site. Several investigators have identified geologic processes and events that could disrupt a radioactive waste disposal facility (Cranwell et al., 1982; Hunter, 1983; Schumm and Chorley, 1983). Examples of these "geomorphic hazards" include changes in stream discharge, sediment load, and base level, which may result from climate change, tectonic processes, or magmatic processes. In the performance assessment, these hazards are incorporated into scenarios that may affect the future performance of the RWMC.

\subsection{Purpose and Scope}

In this report, we address the geologic processes and events that are relevant to the long-term land surface stability of the RWMC during the next 10,000 years. The report focuses on the 
geologic history of the Eastern Snake River Plain (ESRP) and specifically, the RWMC basin. This historical analysis is the basis for predictions of future land surface stability. The report relies on technical information from the specialized fields of geology, geomorphology, pedology, archaeology, geodetics, geochronology, and tectonics. To assist the reader, a detailed glossary of terms has been included in Appendix A.

The 10,000-year time frame was chosen for two reasons. First, while DOE order 5820.2A does not explicitly state a "time frame of compliance," it is recognized that the models used to predict the fate and transport of radionuclides in the environment are speculative at best, and predicting dose beyond 10,000 years is generally not reasonable. NRC has adapted 10,000 years as a time frame for compliance (10 CFR 61, 40 CFR 191), and DOE Performance Assessment Task Team has recommended a 10,000-year period of compliance (DOE, 1994) that is currently being written into the revised DOE order 5820.2A (5820.2B). Second, the geologic record for the past 10,000 years (Holocene Epoch) is relatively complete and accessible to geologic/climatologic study. Predictions for the timing, duration, and magnitude of future geologic and climatologic events for 10,000 years may be made with some degree of confidence.

The analysis in the report is based on assessments of (a) surficial processes and events that have influenced or could influence the RWMC landscape, and (b) lithospheric processes and events, including regional and local tectonism and volcanism. We emphasize surficial processes or events that might lead to the erosion of cover materials, as well as lithospheric processes that might lead to the exposure and release of radionuclides to the atmosphere, soil, or surface water. Although the potential release of wastes into the subsurface, or potential effects of future anthropogenic activities may be relevant, they are outside the scope of this report.

Chapter 2 provides background on each of the surficial and lithospheric processes or events considered in the report. A summary statement of the historical effects of that process on the RWMC is included. The discussion in Section 2.2 (Lithospheric processes) includes more detail because these processes are not considered further in the report. Chapter 3 outlines the regional physiography and geology with a discussion on the present ESRP landscape evolution. Chapter 4 provides detailed information of the RWMC physiography and geology including discussions on the topographic setting, subsurface geology, and surficial geology. Chapter 5 then summarizes all the data into a set of conclusions on the RWMC-specific landscape stability for the next 10,000 years.

\subsection{Geomorphic Concepts}

Geomorphology is the study of the nature, origin, and development of the earth's landforms. Several concepts and assumptions are fundamental to assessment of geomorphic stability: (a) uniformity, (b) evolution, and (c) complexity. In its simplest form, uniformity means that basic physical and chemical relationships that operated within the geologic past can be used to predict future events. Evolution means that landforms change through the ongoing action of geomorphic processes; when these processes are reasonably well understood within an area, the principle of uniformity can be applied to extend the results into the future. The prediction of the shape and behavior of the future landscape is complicated by the possibility for geomorphic processes to be interrupted and redirected by climate change, faulting, or volcanism. 


\subsection{Previous Investigations}

Many geologic investigations pertinent to the geomorphic stability of the RWMC have been conducted at the INEL and are referenced throughout this report. Four RWMC-specific investigations, conducted during 1991-1993, provide much of the detailed data discussed in this report. One study provides a detailed analysis of soil characteristics from locations within and proximal to the RWMC basin. This work identified stratigraphic relationships between eolian and slopewash sediments, and surficial and buried soils (Dechert et al., 1993). The second investigation provided absolute geochronology on several discrete sedimentary units through the use of thermoluminescence (TL) age dating (Forman et al., 1993). The third and fourth studies provided detailed mapping and flood modeling (Rathburn, 1991 and 1993) and precise dating (Cerling et al., 1994) of the glacial outburst floods, which inundated the RWMC basin in the Late Pinedale glaciation. 


\section{GEOLOGIC AND CLIMATOLOGIC PROCESSES IMPORTANT TO RWMC LAND SURFACE STABILITY}

Figure 1 is a summary diagram of geologic processes that have been active on the ESRP and of the estimated annual probability of recurrence on which they operate. The processes with annual probability ranges extending into the shaded zone $(10,000$ years) are considered important for performance assessment. (The reciprocal of the annual recurrence probability gives the time scale on which recurrence is likely.) The probability estimates for surficial processes are based on inference from regional and world-wide examples. The probability estimates for lithospheric (seismic and volcanic) processes are based on INEL- or RWMC-specific quantitative investigations.

Section 2.1 presents a general description of the surficial processes listed on Figure 1 and a summary statement on its observed effects at the RWMC (or surrounding area). Data and detailed descriptions in support of these conclusions are provided in Chapters 3-5. Section 2.2 presents RWMC-specific data on the lithospheric processes listed on Figure 1. Although regional and site descriptions provided in later sections are pertinent to understanding these conclusions, lithospheric processes are not further considered in this report.

\subsection{Surficial Processes}

Hillslopes are subjected to two principal erosional processes, entrainment and mass movement. Entrainment is the transport of materials by water, wind, or ice. Entrainment by water could occur by raindrop impact, sheet wash, or rill and gully runoff during local precipitation events, rapid snowmelt, or flooding of major streams such as the Big Lost River. 'Entrainment by wind can occur when natural stabilizers such as soil crusts or vegetation are disturbed. Entrainment by ice occurs by plucking of materials from a frozen surface. Mass movement is the transport of materials downslope due to gravitational forces. Mass movement involving catastrophic failure (e.g., mudflows, landslides) are not important on the INEL due to low topographic relief. Soil creep is the downslope movement of individual sediment grains by heave mechanisms (generally freeze/thaw). The movement of individual sediment particles by soil creep has not be studied on the ESRP, but is generally believed to be on the order of a few centimeters per year. Data indicate that the hillslopes around the RWMC have been subjected to erosion by these processes, and that sediment has been eroded off the slopes and redeposited on the basin floor.

The RWMC basin (and other areas of the INEL) has experienced basin-derived, historical flooding events. Flooding generally occurs when frozen ground inhibits infiltration of runoff during rapid melting of a significant snowpack, with or without precipitation in the form of rain. Local flooding events enhance erosion of hillslopes by entrainment of sediment, which gets deposited on the basin floor. Basin outflow along the natural channel to the Big Lost River may remove some floodwaters from the basin. No specific evidence has been observed of sediment transport out of the basin along the channel, and it appears that outflow from local basin flooding events does not have sufficient discharge or velocity for sediment transport. However, if these events had a sufficient magnitude, duration, and frequency to transport sediment, they could cause headward erosion into the basin sediments, thus causing removal. 


\section{(Shaded zone important for performance assessment)}

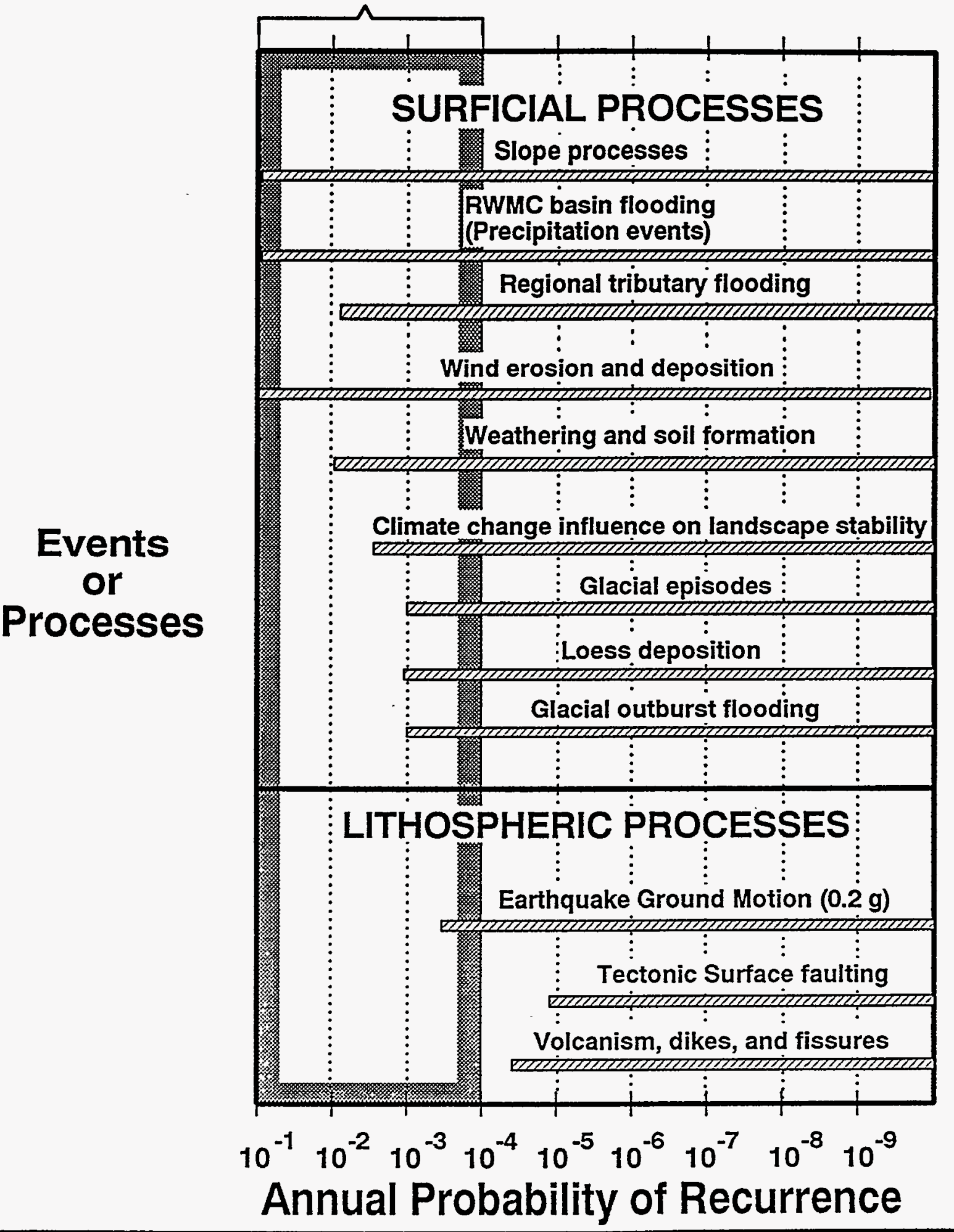

Figure 1. Summary diagram of important ESRP geologic processes or events, and their estimated range of annual recurrence probabilities (hatchered bars). 
Regional tributary flooding refers specifically to flooding of the Big Lost River, which does not currently flow through the RWMC basin (see Section 3.1 for location). However, under natural conditions (upon removal of man-made flood control measures), large-scale floods could enter the basin resulting in deposition or erosion (or both) of sediment. The erosional or depositional nature of a flood event depends on the discharge and velocity of water entering the basin. There is evidence in the RWMC basin of deposition of sand and gravel during historical Big Lost River floods.

Wind erosion and deposition have played a large role in shaping the landscape of the ESRP and RWMC basin. Sediment can be removed by wind entrainment, especially in disturbed areas i.e., man-made-, fire-, or climate-related removal of vegetative cover. Wind (eolian) transport and deposition of fine-grained sediment called loess has smoothed the rugged topography of the older basalt flows on the ESRP. Much of the sediment within the RWMC basin originated by eolian deposition of loess. There is no specific indication that eolian processes have resulted in the removal of significant sediment from the RWMC basin.

Weathering and pedogenesis (soil formation) result in the development of layers, or horizons, of mineral and/or organic constituents of variable thicknesses, which differ from the parent material in their morphological, physical, chemical, and mineralogical properties and their biological characteristics (Birkeland, 1984). The development of recognizable soil profiles in sediment of temperate climates generally requires hundreds to thousands of years of weathering. Development of surficial soils or presence of buried soils (paleosols) has important implications for land surface stability: soil development implies that the land surface was stable, with no erosion or deposition of sediment for extended periods of time. The absence of soil horizons implies two possible scenarios: either (a) the duration of weathering was insufficient for soils to develop prior to deposition of sediment or inundation by lava flows, such that depositional rates exceeded weathering rates, or (b) soils formed but were removed by erosion. In the latter case, evidence of erosion would exist as an unconformity (buried erosional surface) in the stratigraphic record.

Climate change influences landscape stability in complex ways, depending on changes in mean annual temperature and precipitation, and shifting in the seasonality of precipitation events. Locally, climate change can produce different results partially as a result of elevation differences. For example, at high elevations, a change to a colder/wetter climate may result in the erosion of bedrock and deposition of tills by glaciers. At lower elevations (as at the RWMC), response to the same climate change resulted in widespread deposition of windblown sediment (loess) and catastrophic glacial-outburst flooding.

Increased temperature accompanied by reduced precipitation may reduce vegetational cover, thus increasing erosion due to slope wash, soil creep, and entrainment of dust by wind. However, increased temperatures accompanied by increased precipitation may result in altered vegetation communities without increased exposure of surficial sediments. One model of global warming due to emission of greenhouse gases estimates a rate of increase of global mean temperature during the next century of about $0.3^{\circ} \mathrm{C}$ per decade (uncertainty of 0.2 to $0.5^{\circ} \mathrm{C}$ per decade). This model assumes a "business-as-usual" scenario wherein carbon dioxide and methane emissions are expected to increase by 10 to $20 \%$ by the year 2025 . This will result in a global mean temperature increase of about $3^{\circ} \mathrm{C}$ before the end of the next century (Houghton et al., 1990). 
Regional climate changes differ from the global mean, and prediction of regional details has a low confidence. Models predict a 4 to $8^{\circ} \mathrm{C}$ warming in the Rocky Mountain west with a doubling of current $\mathrm{CO}_{2}$ values (Houghton et al., 1990).

Seven complete glacial/interglacial cycles have occurred during the past 620,000 years, with an average duration of 100,000 years. Interglacial episodes (periods similar to the last 10,000 years) have accounted for $39 \%$ of the past 529,000 years (Morrison, 1991). Deep sea isotopic records and ice-core records of the last glacial/interglacial periods have indicated rapid, intense climate fluctuations within century or even decadal time periods (GRIP Project members, 1993;

Dansgaard et al., 1993; Broecker and van Donk, 1970; Barry, 1983). Global surface temperatures have varied from 5 to $7^{\circ} \mathrm{C}$ with 10 to $15^{\circ} \mathrm{C}$ changes in some middle and high latitude regions of the northern hemisphere (Houghton et al., 1990). The present interglacial (called the Holocene) is more stable and has had lower maximum temperatures than the previous interglacial (called the Eemian in Europe, or Sangamon in North America) (Figure 2). The Eemian interglacial experienced rapid temperature fluctuations completed in as little as 10 to 20 years and lasting 70 to 5,000 years (GRIP, 1993). The mechanisms causing the Eemian climate fluctuations may have been related to oceanic and/or atmospheric circulation changes, but are not fully understood. Fluctuations in the Holocene have varied geographically both in temperature and duration; however, worldwide temperatures probably fluctuated by little more than $1^{\circ} \mathrm{C}$ (Houghton et al., 1990).

Loess deposition occurs when fine-grained sediments (predominantly silt) are entrained and transported by wind. Increased fluvial runoff associated with the seasonal thawing of glaciers increases the sediment supply available for transport. Loess may be carried aloft for very long distances prior to deposition in uniform, unstratified "blankets," which generally cause a smoothing of the preexisting landscape. Loess may remain in a stable configuration, maintaining a vertical

exposure for thousands of years. Reworked loess, e.g., eroded and transported by hillslope and/or fluvial processes, is typically stratified (layered) upon redeposition. Loess is one of the primary sediments covering basalt flows on the ESRP. At least two loess units have been identified in the RWMC basin, both of which were stable for a long enough duration to allow for pedogenesis.

Glacial outburst floods occur when meltwater is released from a glacier-dammed lake usually due to lifting of the ice dam by buoyant forces. These floods may be annual events, or may occur only during the waning stages of a glacial period. Flooding is often very large scale and may be catastrophic. There is evidence that the RWMC basin has been inundated by glacial-outburst floods at least once toward the end of the last glaciation (Pleistocene).

\subsection{Lithospheric Processes}

Earthquake ground motion of $0.3 \mathrm{~g}$ (two-tenths of the acceleration due to gravity) has a probability of recurrence of about $1 \times 10^{-4} / \mathrm{yr}$ (corresponding to a return period of 10,000 years) at the RWMC (Wong et al., 1995). This conclusion is based on paleoseismic investigations of nearby faults and the seismic hazard assessment of INEL facilities. The faults considered in the assessment are the Lost River and the Lemhi Faults (see Figure 6 for locations), each of which has the potential to generate a magnitude 7 to 7.3 earthquake with an epicenter near the north margin of the ESRP. Such an earthquake on the southern part of the Lost River fault (the 


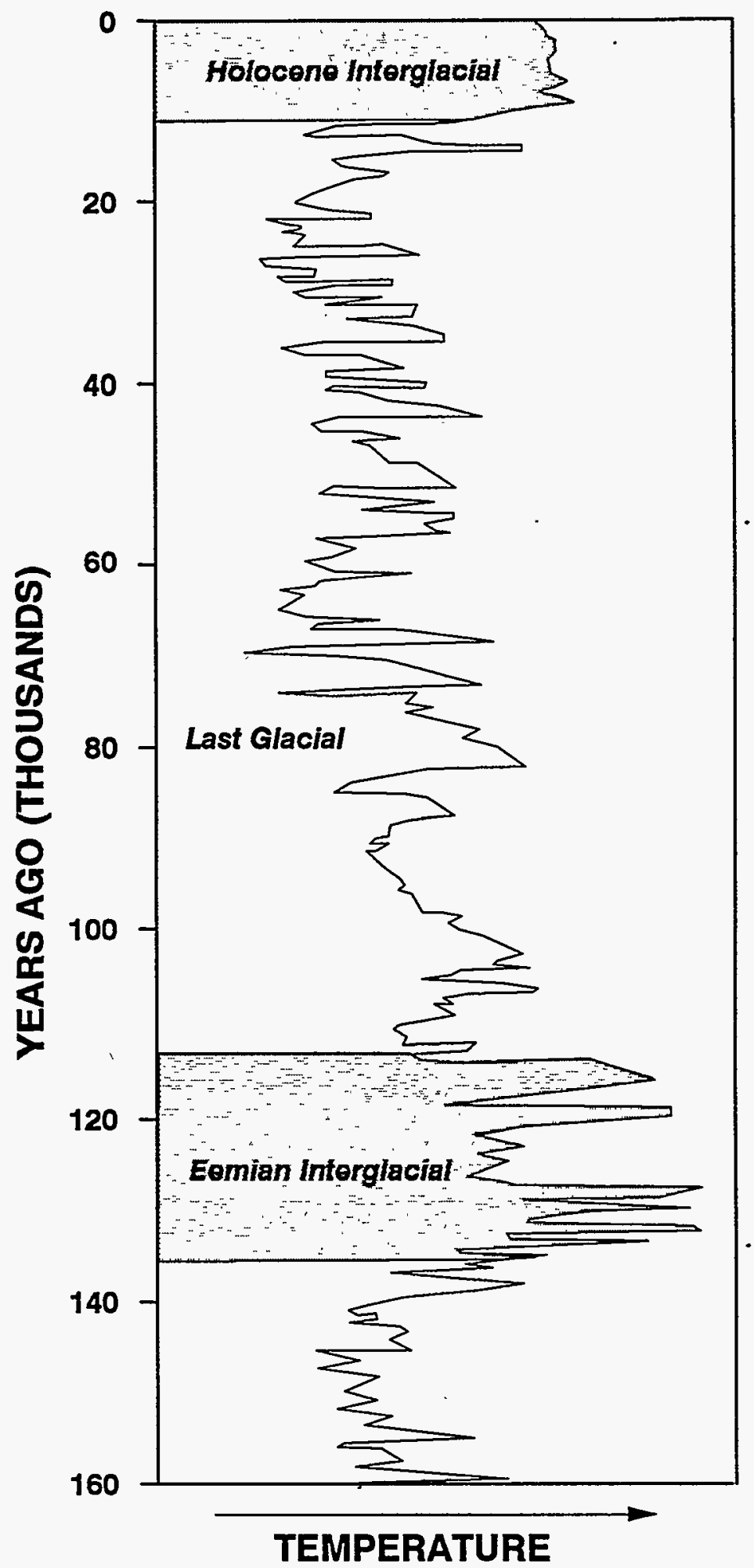

Figure 2. Glacial/interglacial temperature fluctuations (modified from Kerr, 1993). 
closer of the two to RWMC) will produce the $\approx 0.3-\mathrm{g}$ ground motion at RWMC. Other earthquake sources considered in the assessment are the Arco volcanic rift zone (see Figure 5 for locations) and a background ESRP source. Neither of these additional potential seismic sources will produce greater ground motions at RWMC than approximately $0.3 \mathrm{~g}$.

Most engineered and buried structures, including buried waste at the RWMC, will easily withstand such accelerations, and the release of buried radionuclides seems unlikely. Stronger ground motions (those approaching $1.0 \mathrm{~g}$ ) could be potentially damaging, but have such low annual probabilities of recurrence, given the present configuration of tectonic elements (described in Section 3), that they are not considered further in this report.

Surface faulting could significantly disrupt the ground surface and potentially expose RWMC buried waste, but the probability of ESRP surface faulting associated with tectonic activity is considered to be very low because tectonic faults do not currently encroach into the RWMC area and have not done so for at least the past few hundred thousand years. Substantive change from the present tectonic configuration and pattern of regional faulting, involving the encroachment of tectonic faults onto the RWMC site, would likely require several hundred thousand years or more. Surface faulting as a result of tectonic activity does not warrant further consideration in this report.

Volcanism, together with the related phenomena of dike intrusion and dike-induced ground deformation, have a probability of recurrence at RWMC of about $8 \times 10^{-6} / \mathrm{yr}$, based on the eruptive history and distribution of INEL volcanic rocks (Kuntz et al., 1994; Volcanism Working Group, 1990; Hackett and Smith, 1994) (Table 1). This corresponds to an average return period of about 125,000 years and, over the 10,000-year period of interest, results in a 0.08 probability of occurrence. For a comprehensive summary of the recurrence probabilities and potential effects of volcanic events at RWMC, see Hackett (1993) and Hackett and Smith (1994). 
Table 1. Estimated volcanic-recurrence intervals for volcanic zones and borehole sites of the RWMC area (with corresponding annual probabilities of recurrence given in parentheses). Although its eruptions would not likely affect the RWMC, the Great Rift is included because it is a probable area of future volcanism on the ESRP, and it gives a bounding value of minimum recurrence (shortest return interval) for the ESRP. Recurrence intervals "(1)" are based on counting of individual vents and fissures, an extremely conservative procedure that yields bounding values of minimum recurrence (shortest intervals). Recurrence intervals "(2)" are based on grouping of vents and fissures into geologically reasonable sets according to (a) the assumption that vent/fissure groups each cover a $2 \times 5-\mathrm{km}$ geographic area (based on observed areas of vent/fissure sets that are known to be products of discrete ESRP fissure eruptions), (b) consistency with geologic-map relations, and (c) other factors such as northwest alignment of the vent/fissure groups and professional judgement concerning the spatial relationships of vents and fissures within the context of magmatic processes.

\begin{tabular}{|c|c|c|c|c|c|}
\hline $\begin{array}{l}\text { VOLCANIC ZONE } \\
\text { OR BOREHOLE }\end{array}$ & \begin{tabular}{|l} 
DATA \\
SOURCES
\end{tabular} & \begin{tabular}{|l|} 
TIME INTERVAL \\
OF voLCANISM \\
[yrs before present]
\end{tabular} & $\begin{array}{l}\text { NUMBER OF VENTS, } \\
\text { FISSURES OR FLOW } \\
\text { GROUPS }\end{array}$ & COMMENTS & \begin{tabular}{|l} 
ESTIMATED \\
RECURRENCE \\
INTERVAL
\end{tabular} \\
\hline $\begin{array}{l}\text { Great Rift } \\
\text { ( } 25 \mathrm{~km} \text { southwest of } \\
\text { INEL) }\end{array}$ & $\begin{array}{l}\text { Kuntz et al., } \\
1986,1988\end{array}$ & $\begin{array}{l}2,100-15,000 \text { yrs } \\
\text { (radiocarbon dating) }\end{array}$ & $\begin{array}{l}>100 \text { vents } \\
8 \text { Holocene enuptive } \\
\text { periods (each lasting a few } \\
\text { decades or centuries, and } \\
\text { each including multiple } \\
\text { flows and cones). }\end{array}$ & $\begin{array}{l}\text { no impact on INEL; } \\
\text { most recently and frequently } \\
\text { active of all ESRP rift zones; } \\
\text { thus provides minimum- } \\
\text { recurrence for entire ESRP; } \\
\text { most probable area of future } \\
\text { ESRP volcanism } \\
\end{array}$ & $\begin{array}{l}2,000 \text { yrs } \\
\left(5 \times 10^{-4} / y r\right)\end{array}$ \\
\hline $\begin{array}{l}\text { Axlal Volcanic Zone } \\
\text { (southern INEL) }\end{array}$ & $\begin{array}{l}\text { Kuntz et al., } \\
1986,1994\end{array}$ & $\begin{array}{l}5,000-730,000 \text { yrs } \\
\text { (K-Ar dating; } \\
\text { radiocarbon; } \\
\text { paleomagnetic data) }\end{array}$ & \begin{tabular}{|l|}
73 vents \& fissure sets; \\
4 Holocene lava fields, \\
3 of them shared by \\
volcanic rift zones. \\
45 cogenetic vent/fiss gps \\
\end{tabular} & $\begin{array}{l}\text { could affect much of southern } \\
\text { INEL; most recently and } \\
\text { frequently active of all volcanic } \\
\text { zones that could impact INEL }\end{array}$ & $\begin{array}{l}16,000 \text { yrs } \\
\left(6.2 \times 10^{-5} / y r\right)\end{array}$ \\
\hline $\begin{array}{l}\text { Arco } \\
\text { Volcanic RIft Zone } \\
\text { (southwestern INEL) }\end{array}$ & $\begin{array}{l}\text { Kuntz, 1978; } \\
\text { Smith et al., } \\
\text { 1989; Kuniz } \\
\text { et al., } 1994 \\
\end{array}$ & $\begin{array}{l}10,000-600,000 \text { yrs } \\
\text { (radiocarbon, K-Ar and } \\
\text { TL dating; } \\
\text { paleomagnetic data) }\end{array}$ & $\begin{array}{l}83 \text { vents \& fissure sets; } \\
2 \text { Holocene lava fields. } \\
35 \text { cogenetic vent/fiss gps }\end{array}$ & $\begin{array}{l}\text { volcanism could affect } \\
\text { southwestern INEL }\end{array}$ & $\begin{array}{l}17,000 \mathrm{yrs} \\
\left(5.9 \times 10^{-5} / \mathrm{yr}\right)\end{array}$ \\
\hline $\begin{array}{l}\text { Lava Ridge-Hells } \\
\text { Half Acre Volcanic } \\
\text { Rift Zone (Includes } \\
\text { Circ Butte/Kettle } \\
\text { Butte volc rift zone) } \\
\text { (north \& eastern INEL) } \\
\end{array}$ & $\begin{array}{l}\text { Kuntz et al., } \\
1986,1994\end{array}$ & $\begin{array}{l}5,000-1,200,000 \text { yrs } \\
\text { (K-Ar dating; } \\
\text { radiocarbon; } \\
\text { paleomagnetic data) }\end{array}$ & \begin{tabular}{|l|}
48 vents \& fissure sets; \\
1 Holocene lava field: \\
Hells Half Acre. \\
30 cogenetic vent/fiss gps
\end{tabular} & $\begin{array}{l}\text { could affect northern \& } \\
\text { eastern INEL; extremely long } \\
\text { eruptive history; includes } \\
\text { oldest and youngest basalts in } \\
\text { the INEL area }\end{array}$ & $\begin{array}{l}40,000 \text { yrs } \\
\left(2.5 \times 10^{-5} / y r\right)\end{array}$ \\
\hline $\begin{array}{l}\text { Howe-East Butte } \\
\text { Volcanlc Rift Zone } \\
\text { (central INEL) }\end{array}$ & $\begin{array}{l}\text { Kuntz, 1978, } \\
\text { 1992; Golder } \\
\text { Associates, } \\
1992 \\
\end{array}$ & $\begin{array}{l}230,000-730,000 \text { yrs } \\
\text { (K-Ar dating; } \\
\text { paleomagnetic data) }\end{array}$ & $\begin{array}{l}7 \text { vents \& fissure sets; } \\
\text { no Holocene features. } \\
5 \text { cogenetic vent/fissure } \\
\text { groups }\end{array}$ & $\begin{array}{l}\text { old, poorly exposed and } \\
\text { sediment-covered; identified } \\
\text { in part by subsurface } \\
\text { geophysical anomalies }\end{array}$ & $\begin{array}{l}100,000 \mathrm{yrs} \\
\left(1.0 \times 10^{-5} / \mathrm{yr}\right)\end{array}$ \\
\hline $\begin{array}{l}\text { Borehole } \\
\text { NPR SITE E } \\
\text { (south-central INEL), }\end{array}$ & $\begin{array}{l}\text { Champion et } \\
\text { al., } 1988\end{array}$ & $\begin{array}{l}230,000-640,000 \text { yrs } \\
\text { (K-Ar dating; } \\
\text { paleomagnetic data) }\end{array}$ & $\begin{array}{l}9 \text { lava-flow groups } \\
\text { (each group contains } \\
\text { multiple flows, erupted } \\
\text { over a short time) } \\
\end{array}$ & $\begin{array}{l}\text { dates from } 600 \text {-foot interval of } \\
\text { subsurface lavas give recur- } \\
\text { rence estimate consistent with } \\
\text { surticial geology of the area }\end{array}$ & $\begin{array}{l}45,000 \text { yrs } \\
\left(2.2 \times 10^{-5} / y r\right)\end{array}$ \\
\hline $\begin{array}{l}\text { Borehole } \\
\text { RWMC 77-1 } \\
\text { (southwestern INEL) }\end{array}$ & $\begin{array}{l}\text { Kuntz, 1978; } \\
\text { Anderson \& } \\
\text { Lewis, } 1989\end{array}$ & $\begin{array}{l}100,000-565,000 \text { yrs } \\
\text { (K-Ar and TL dating; } \\
\text { paleomagnetic data) }\end{array}$ & $\begin{array}{l}11 \text { lava-flow groups (each } \\
\text { group contains multiple } \\
\text { flows, erupted over a short } \\
\text { time) }\end{array}$ & $\begin{array}{l}\text { dates from } 600 \text {-foot interval of } \\
\text { subsurface lavas give longer } \\
\text { recurrence interval than } \\
\text { nearby Arco \& Axial zones, } \\
\text { reflecting flow-group (sub- } \\
\text { surface) vs. vent-counting } \\
\text { (surface geology) approaches }\end{array}$ & $\begin{array}{l}45,000 \mathrm{yrs} \\
\left(2.2 \times 10^{-5} / \mathrm{yr}\right)\end{array}$ \\
\hline
\end{tabular}




\section{REGIONAL PHYSIOGRAPHY AND GEOLOGY}

\subsection{Physical Setting}

The INEL is located near the northern margin of the ESRP and lies in an area influenced by two distinct geologic provinces. The ESRP is a broad, low-relief basin filled by silicic volcanic rocks, basaltic lava flows, and terrestrial sediment (Figure 3). It is 90 to $100 \mathrm{~km}$ wide and about $350 \mathrm{~km}$ long (Malde, 1991), with elevations ranging from about 2,000 $\mathrm{m}$ in its northeastern part to about $1,300 \mathrm{~m}$ near Pocatello. The ESRP is flanked to the northwest and southeast by the mountains of the Basin and Range Province, and grades northeastward onto the Yellowstone Plateau. The basin-and-range mountains trend north to northwest, with peaks as high as $3,700 \mathrm{~m}$ and a maximum total relief of about $2,400 \mathrm{~m}$. Basins between the mountain ranges are 5 to $20 \mathrm{~km}$ wide and drain onto the ESRP.

The topographic relief of the ESRP is about $200 \mathrm{~m}$ and is subdued with respect to the surrounding mountains and plateaus. Elevations in the vicinity of the INEL range from $1,460 \mathrm{~m}$ at the Big Lost River Sinks, to about $1,650 \mathrm{~m}$ along the axial volcanic zone. Four prominent buttes exist on the broad volcanic highland along the axis of the ESRP (the axial volcanic zone) and provide additional local relief of 120 to $650 \mathrm{~m}$ : Big Southern Butte (2,308 m), Cedar Butte $(1,776 \mathrm{~m})$, Middle Butte (1,984 m), and East Butte (2,003 m) (Figure 4).

The Snake River flows along the southern margin of the ESRP and is joined by tributaries from the basin-and-range mountains to the south. To the north, three major streams emerge from the basin-and-range mountains north and west of the INEL: the Big Lost River, the Little Lost River, and Birch Creek. These streams join in a series of sinks and playas in the northcentral INEL where the water infiltrates and contributes to recharge of the Snake River Plain Aquifer (Figure 4).

Basaltic volcanism strongly affects the internal drainage pattern of the ESRP, which has many basins that are not connected into an ordered drainage system. Numerous small basins are situated on the highly irregular surfaces of the lava flows and in the low-lying areas between lava flows. Many of these basins, or playas, have no outlet for internal drainage from snowmelt or precipitation. This is largely due to repeated terrain modification by addition of lava flows. In addition, the high permeability of the fractured basalt and the poorly consolidated sediments underlying most of the ESRP inhibit channel development due to loss of surface water by infiltration. Therefore, streams tend to be intermittent, follow lava-flow contacts and lava channels, and commonly end in closed depressions.

\subsection{Geologic Processes and ESRP Landscape Evolution}

Geologic processes or events that have affected the ESRP landscape can be divided into two categories: lithospheric and surficial. Lithospheric processes have included basin-and-range faulting, migration of the Yellowstone hotspot, crustal subsidence, basaltic volcanism, and emplacement of rhyolite domes. Surficial processes respond to climate changes to affect deposition and erosion of sediment. These phenomena have combined at different times and with different periods of duration to develop the present day landscape of the ESRP over the past 10 million years ago. They are discussed below in approximate order of inception. 


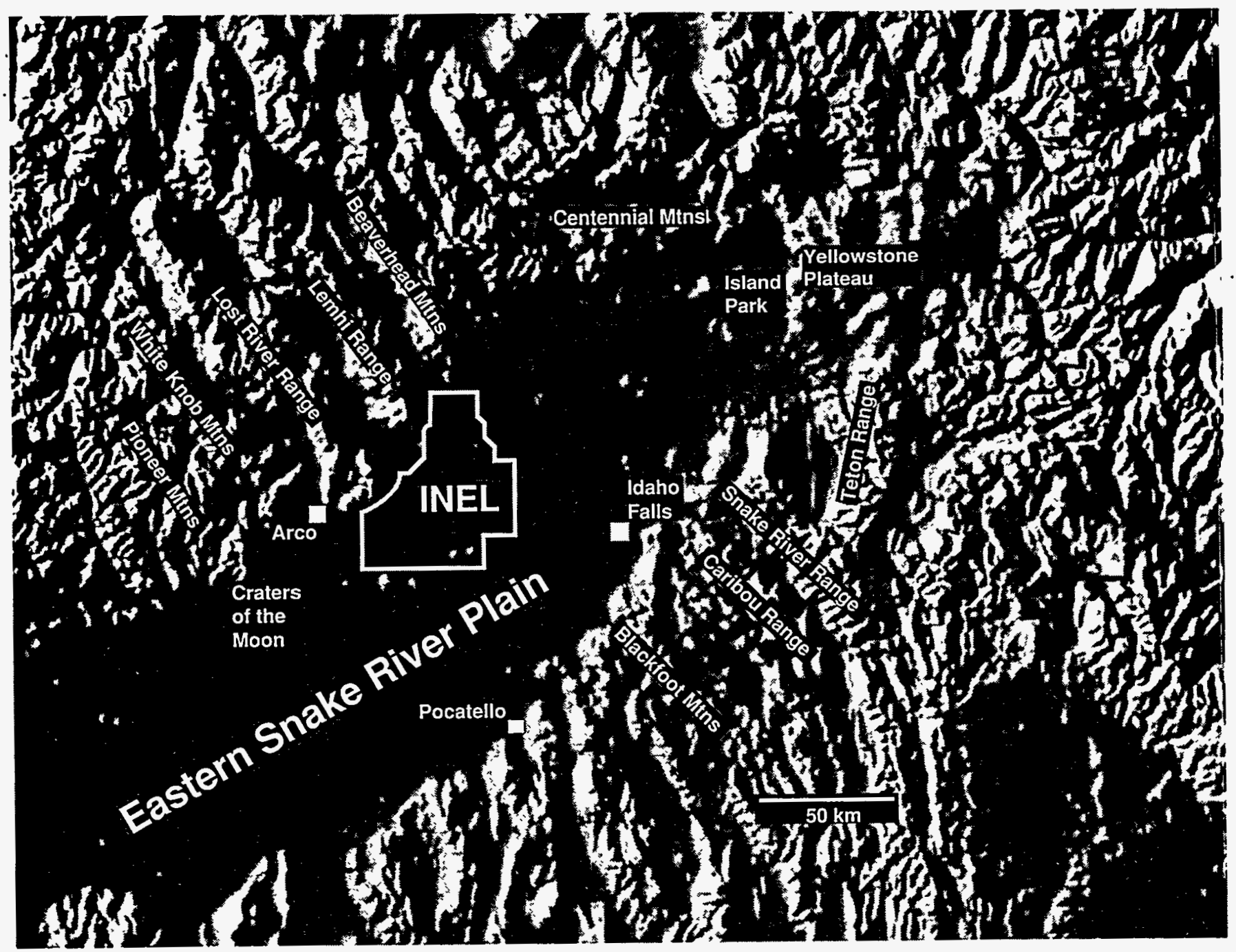

Figure 3. Computer-generated, digital-topographic map of the INEL region (from Thelin and Pike, 1991), showing the strong physiographic contrast between the ESRP and the surrounding basin-and-range province. 


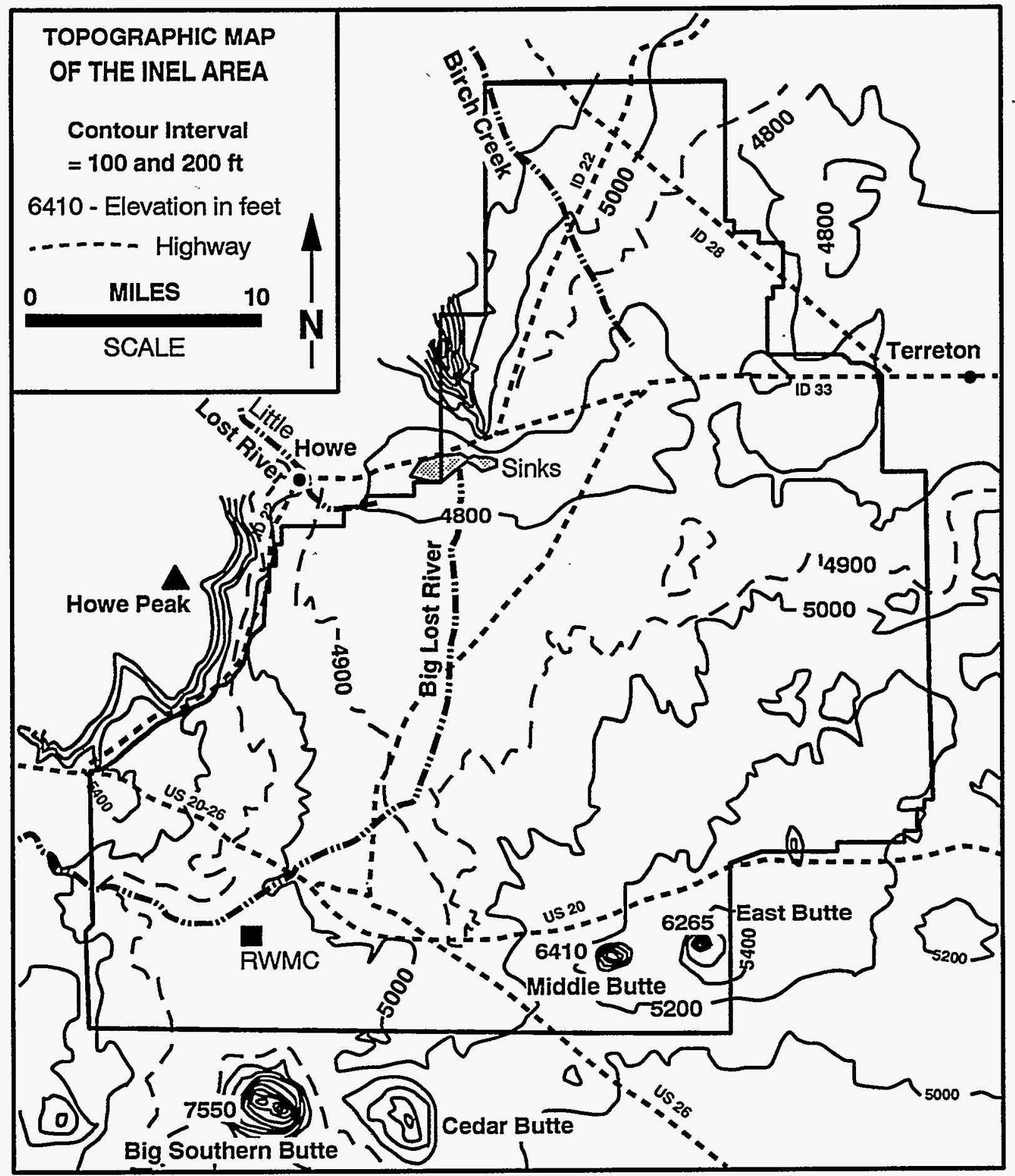

Figure 4. Generalized topographic and drainage map of the INEL area. 
Extension of the earth's crust along north-trending normal faults probably began in southern Idaho before the Yellowstone hotspot arrived beneath the ESRP area (Anders and Sleep, 1993; Rodgers et al., 1990). Basin-and-range mountains surrounding the ESRP have been uplifted by recurrent faulting, and their erosion has supplied most of the sedimentary material brought onto the ESRP. Portions of the normal faults along the western flanks of the Lost River Range, Lemhi Range, and Bitterroot Mountains adjacent to the ESRP are still active, as evidenced by the 1983 Borah Peak, Idaho earthquake. These faults therefore may constitute an earthquake hazard to INEL facilities.

The Yellowstone hotspot is a rising plume within the earth's mantle that impinges on the base of the continental lithosphere, causing widespread uplift of the land surface, melting of both mantle and crustal rocks, and volcanism (Rodgers et al., 1990; Pierce and Morgan, 1992). The earliest manifestation of the Yellowstone hotspot is the presence of 15 to 16 million-year-old silicic volcanic centers in north-central Nevada (Figure 5). These centers become progressively younger toward the northeast, as a result of southwestward relative movement of the North American continent over the fixed hotspot, at a rate of 3 to $4 \mathrm{~cm} / \mathrm{yr}$. The hotspot was under the INEL area of the ESRP about 6.5 to 4.5 million years ago, and the silicic volcanic centers of the Heise volcanic field were formed then (Morgan, 1992). The plume or hotspot is currently believed to underlie the 0.6 million-year-old Yellowstone caldera.

When the Yellowstone hotspot was beneath the ESRP and the INEL region, thermal expansion of the crust, emplacement of magmas into the middle crust, and buoyant forces associated with the upwelling hotspot probably produced a $2.5 \mathrm{~km}$-high plateau over the area, similar to the modern configuration of the Yellowstone Plateau (Pierce and Morgan, 1992; Anders and Sleep, 1993). Subsidence of the ESRP surface to its present average elevation of about $1,500 \mathrm{~m}$ is ascribed to the combined effects of thermal contraction (Blackwell, 1989) and to loading of the crust by the intrusion of dense, mantle-derived magma (Anders and Sleep, 1993).

A long-term subsidence rate for the ESRP can be estimated by assuming that the ESRP surface elevation 4.3 million years ago (prior to burial of the silicic volcanics by basalt) was similar to that of Yellowstone today $(2,500 \mathrm{~m})$, and that the present elevation of that paleosurface is about $500 \mathrm{~m}$ (about $1,000 \mathrm{~m}$ of accumulated basalt and sediment must be subtracted from the present 1,500-m elevation of the ESRP land surface). This results in an average subsidence rate of about $0.5 \mathrm{~km} / \mathrm{million}$ years, or $0.5 \mathrm{~mm} / \mathrm{yr}$. Analysis of first-order geodetic leveling lines across the ESRP (Reilinger et al., 1976; Pelton, 1991) and the stratigraphic relationships of basalts and sediments beneath the INEL (Anderson and Lewis, 1989) indicate that subsidence of the ESRP is continuing at present.

Subsidence of the ESRP after passage of the Yellowstone hotspot was accompanied by extrusion of basaltic magma. Basalt lava flows constitute the bulk of ESRP basin-filling material. Eruptions largely involved mild effusions of fluid lava from fissures and broad, low shield volcanoes. Repeated eruptions, along with accumulation of sediments in low areas, have produced the low-relief surface of the ESRP.

Volcanic vents are not randomly distributed on the ESRP, but are concentrated in a northeast-trending zone along the central axis of the ESRP, called the axial volcanic zone (Hackett and Smith, 1992). Also present are northwest-trending belts of vents, fissures, and small 


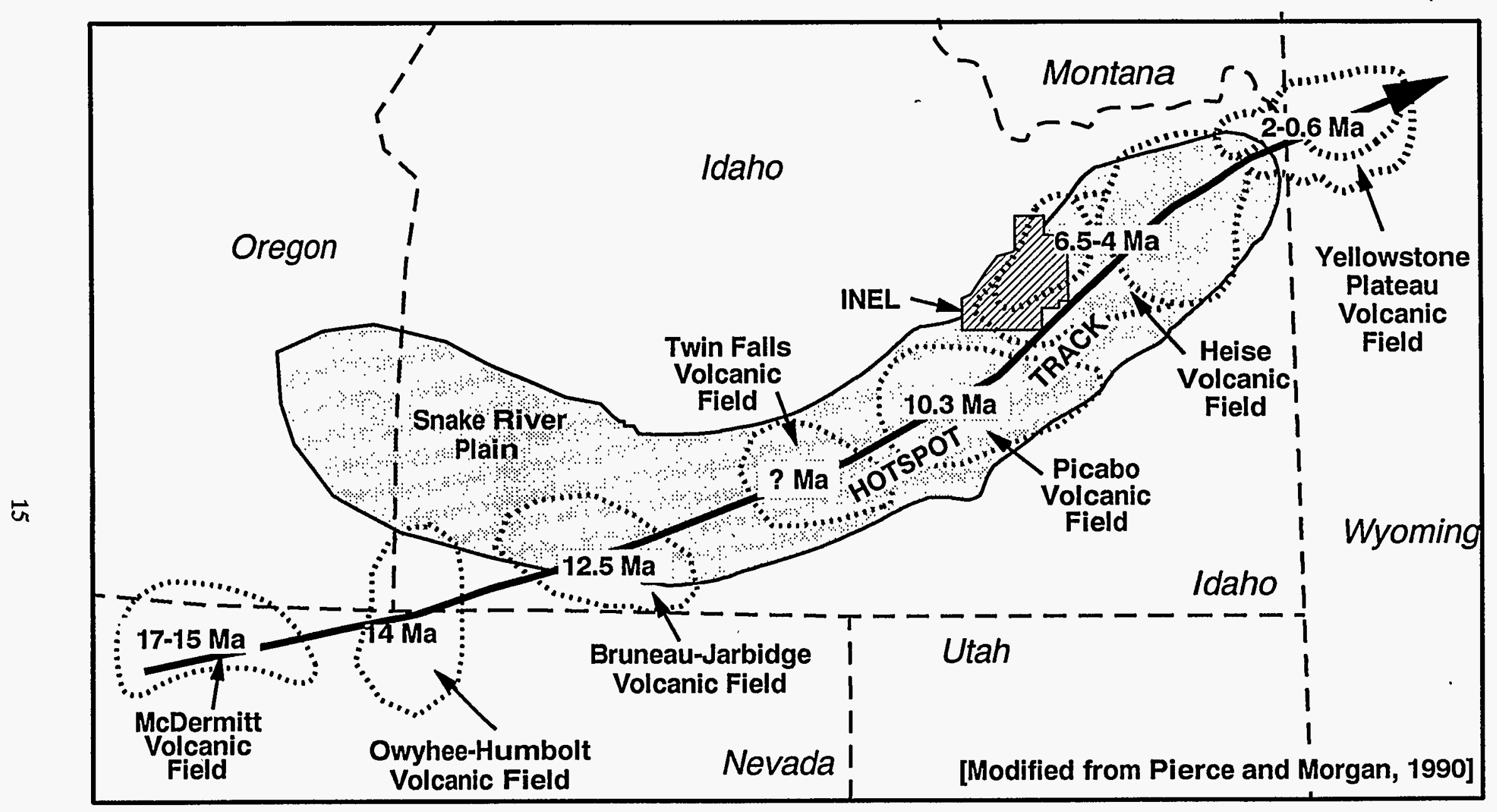

Figure 5. Positions and ages of silicic volcanic centers associated with passage of the Yellowstone hotspot (adapted from Pierce and Morgan, 1992). 
normal faults, known as volcanic-rift zones (Kuntz et al., 1992) (Figure 6). Basalts exposed at the ESRP surface near the INEL range in age from 2,100 years old to more than a million years old. Quaternary basalts are divided into five groups based on their measured or estimated ages (Figure 7).

Several rhyolite domes formed along the axial volcanic zone within the past million years (Kuntz et al., 1990): Big Southern Butte and East Butte are prominent examples. Middle Butte, an uplifted cylinder of basalt lava flows, is interpreted to be the surface expression of a subsurface rhyolitic dome. Volcanic domes are formed by the slow effusion of extremely viscous lava, and shed a carapace of blocky rubble as they are fed internally by flux of new magma. The rhyolite of these domes is distinctly younger and differs in composition from the earlier voluminous, explosive eruptions of rhyolitic pyroclastics associated with passage of the Yellowstone hotspot (Leeman, 1982).

Sediments deposited on the subsiding ESRP throughout the late Tertiary and Quaternary periods provide important data about climate changes. Pollen data from central Idaho indicate cool, dry conditions with the occurrence of sagebrush-salt bush steppe and the development of saline lakes during the early to middle Pleistocene. However, conditions during glacial intervals were probably substantially cooler (perhaps 5 to $10^{\circ} \mathrm{C}$ ) and wetter, with conifers invading parts of the Snake River Plain (Barnosky et al., 1987; Thompson, 1991).

The Holocene epoch (the last 10,000 years) is defined by the recession of the last continental glaciation (Wisconsin) and initiation of "modern" or interglacial conditions, changes in the distribution and species composition of vegetation communities, the extinction of several Pleistocene megafauna species, shifts in the taxonomic diversity, abundance and distribution of vertebrates that survived extinction, and firm evidence for human occupation of North and South America. Understanding climate variability during the current Holocene interglacial epoch is important, but surprisingly little is known about postglacial climate change. Climatic changes for the late Pleistocene-Holocene of the SRP, Northern Rocky Mountains, and northern Great Basin are complex, due mainly to topography and the interaction of major moisture-bearing atmospheric currents and seasonal storm systems. These factors, which intersect and are amplified by higher elevations just to the east of the SRP in the northern Rocky Mountains and Yellowstone Plateau, produce the mosaic vegetation patterns of today and the past. Vegetational communities respond to changes in climate by moving to higher or lower elevation positions in accordance with preferred temperature and precipitation regimes. Table 2 is a summary of climatic patterns detected through paleovegetation analysis of the past 16,000 years in the ESRP region. The information is drawn mainly from palynological analyses (pollen studies), augmented by sedimentology, plant macrofossil studies, and vertebrate paleontology, and chronology established via radiocarbon dates and volcanic ash layers. Early Holocene $(10,000$ to 7,000 years ago) pollen records from eastern Idaho lakes and packrat middens indicate a general drying trend toward a mid-Holocene xeric maximum (Table 2). Elevational displacements of steppe vegetation probably occurred in response to changing insolation (Davis and Sheppard, 1986).

Holocene vegetation varied with factors of local topography (aspect, elevation), degree of disturbance, and edaphic conditions, but followed a general response to the end of the last glacial period. This response was influenced by changes in atmospheric circulation, which produced dry conditions in summer (the post-glacial and current ESRP pattern) versus dry conditions in winter 


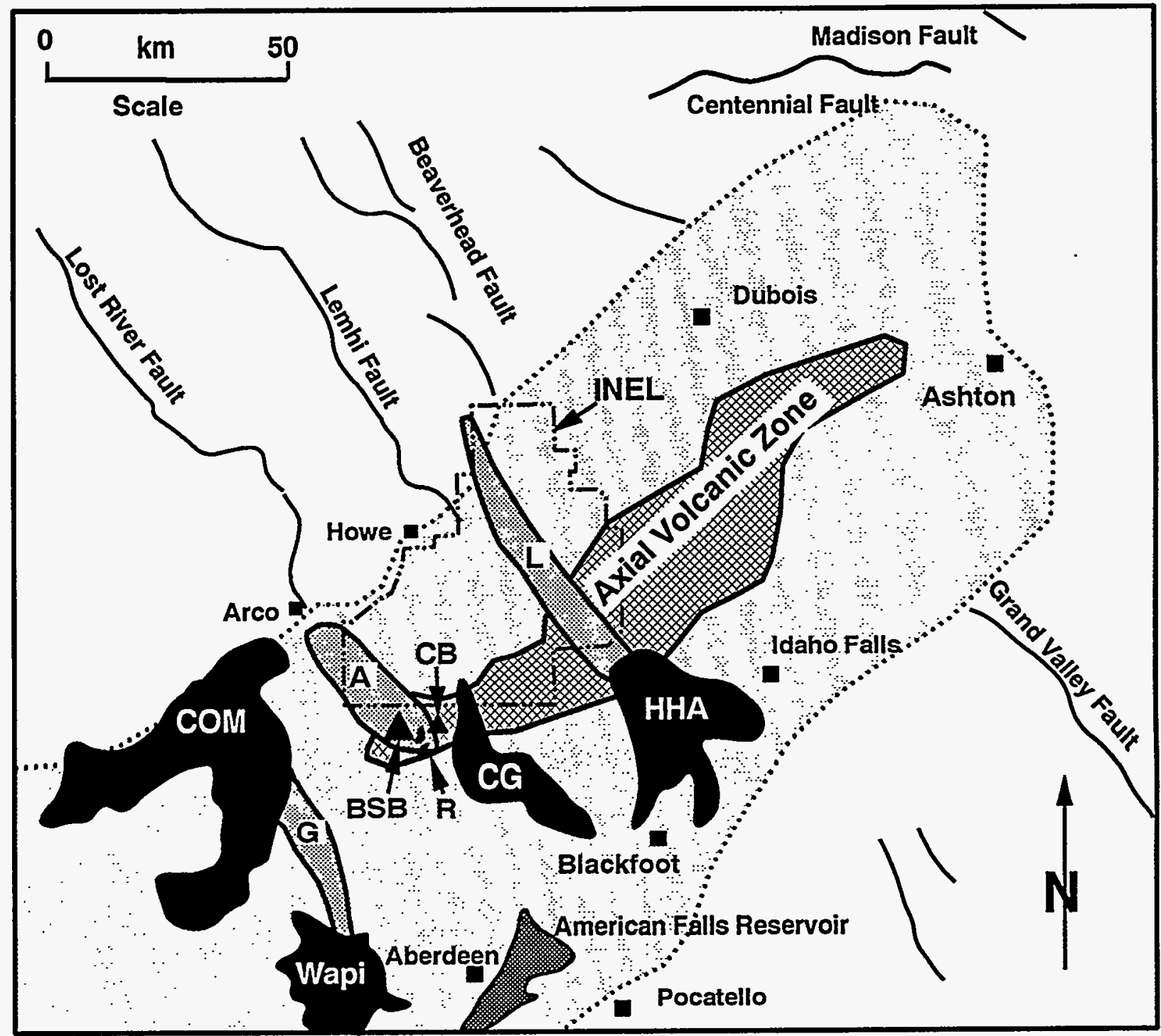

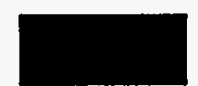

Holocene Lava Fields

COM=Craters of the Moon $\mathrm{CG}=$ Cerro Grande

HHA=Hells Half Acre $R=$ North \& South Robbers

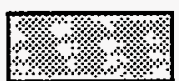

Volcanic Rift Zones

L=Lava Ridge-Hells Half Acre $A=$ Arco G=Great Rift

Figure 6. Holocene lava fields, volcanic-rift zones, and axial volcanic zone of the ESRP. 


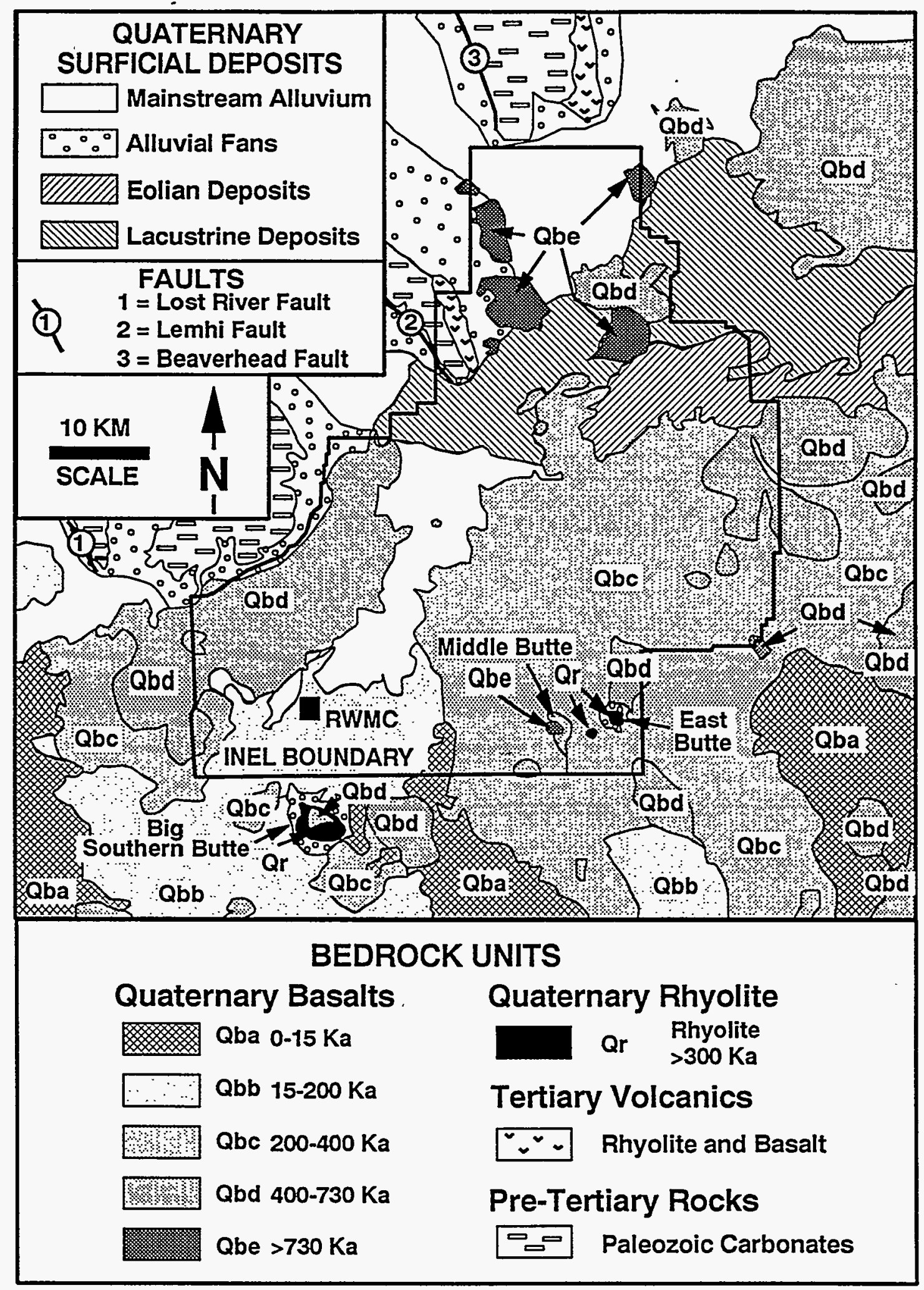

Figure 7. Generalized geologic map of the INEL area, showing the distribution of major basalt lava-flow groups and sedimentary deposits (from Hackett and Smith, 1992; based on information contained in Scott, 1982; and Kuntz et al., 1990). Traces of major basin-and-range tectonic faults north and west of the INEL are indicated: 1. Lost River fault; 2. Lemhi fault; and 3. Beaverhead fault. 
Table 2. Late Pleistocene-Holocene climate and chronology of the ESRP and vicinity. These studies are based primarily on analysis of pollen from lake, bog, and cave deposits, supplemented by ecologic information from plant macrofossils, tree rings, vertebrate and invertebrate fossils, charcoal from wildfires, and characteristics of sediments. Chronologies were established by radiocarbon dating and volcanic ashes. Environmental conditions are relative from past to present.

\begin{tabular}{|c|c|c|c|c|c|c|c|c|c|}
\hline 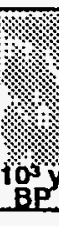 & 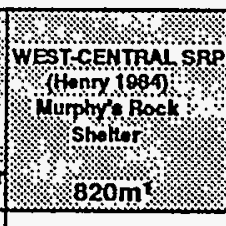 & 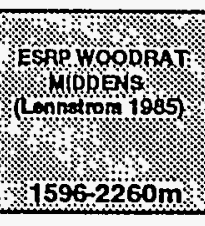 & 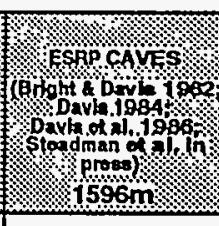 & 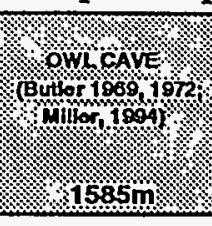 & 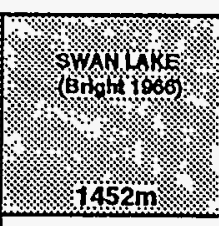 & 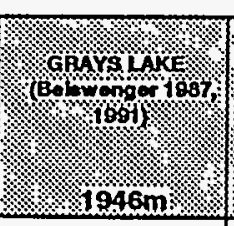 & 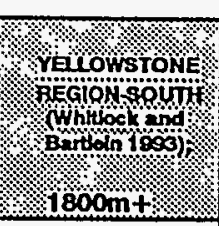 & 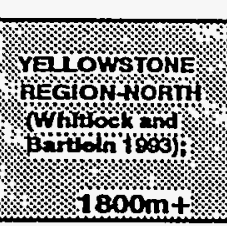 & 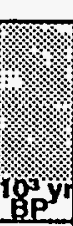 \\
\hline 0 & & & & & & & & & \multirow{5}{*}{$\begin{array}{l}0 \\
1 \\
2 \\
3 \\
4\end{array}$} \\
\hline 1 & & \multirow{8}{*}{$\begin{array}{l}\text { WARM AND DRY } \\
\text { (MODEAN) }\end{array}$} & \multirow{7}{*}{$\begin{array}{l}\text { WETERR AND/OR } \\
\text { COOLER }\end{array}$} & \multirow[b]{2}{*}{ COOLERWETIER } & WARMER & \multirow{2}{*}{ 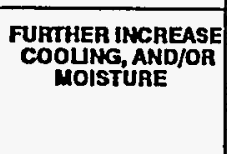 } & \multirow{4}{*}{$\begin{array}{l}\text { COOLER AND } \\
\text { MOISTER THMN } \\
\text { BEFOHE }\end{array}$} & an & \\
\hline 2 & COOLER/WETTER & & & & COOLER & & & & \\
\hline 3 & & & & & & & & ipis & \\
\hline $\begin{array}{l}4 \\
5\end{array}$ & $\begin{array}{l}\text { GRADUAL } \\
\text { IATMATION }\end{array}$ & & & & & COOLER & & & \\
\hline 6 & CUOWH WESTER & & & un op & 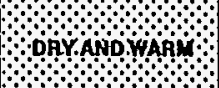 & WETTER & $\because$ & инин & 6 \\
\hline 7 & and & & & & $\cdots$ & & & $\because \cdots$ & $\boldsymbol{r}$ \\
\hline 8 & की & & & की & 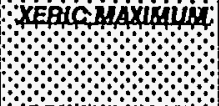 & मnupus & 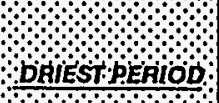 & WETPERENAN & • \\
\hline 10 & 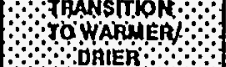 & & DAYANOYARL & & opYAQp & ophen AND & & 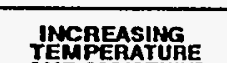 & 9 \\
\hline 11 & 3 & $? 27$ & 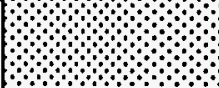 & COOLPWETER & & 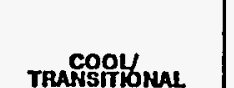 & 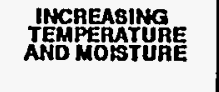 & AND MOISTURE & 11 \\
\hline 12 & & & & ? & $?$ & colpmoist & & & 12 \\
\hline 13 & & & COLD AND DRY & & & & $\begin{array}{l}\text { COOLER THAN } \\
\text { PRESENT }\end{array}$ & THAN & 13 \\
\hline 15 & & & & & & & DEGLACLATION & THARME⿰月⿴囗大 & \\
\hline 16 & & & & & & & & & 16 \\
\hline
\end{tabular}

'Elevation of study site(s).

KEY: Begin and end xeric perlod

ESRP Eastern Snake Rlver Plain

??? Unknown environmental conditions

BP Unknown environmental conditions 
(the northern Yellowstone monsoonal southwest and midwestern plains pattern) (Thompson et al., 1993). For example, within the ESRP region, the Holocene xeric maximum [the "Altithermal" or "Hypsithermal" of Antevs (1948)] is detectible, but varies significantly in timing, duration, and magnitude. The development of longitudinal and parabolic dunes on the ESRP is strong geomorphic evidence for period(s) of pronounced aridity. Preliminary investigations suggest that these dunes were active at some point during the Holocene (Greeley and King, 1977; Forman, unpublished data); however, detailed study is necessary to determine the relative and/or absolute age of dune activity.

Following the hot/dry period of the Altithermal (Table 2), a worldwide trend toward a cooler/wetter climate caused renewed growth of alpine glaciers. The climate underwent multiple low-order changes that resulted in fluctuating glacier activity both regionally and globally. The term "neoglacial" is used to describe the renewed glacial activity immediately following the Altithermal and encompasses all subsequent fluctuations. There is evidence for re-expansion of pluvial Lake Terreton on the ESRP about 700 years ago, possibly coincident with neoglaciation (Bright and Davis, 1982). Additionally, five episodes of glacial expansion have been identified in the Lemhi Range starting 340 years ago (Knoll, 1977). A warming trend (worldwide increase of $\approx 1^{\circ} \mathrm{C}$ ) occurred at the end of the 19 th century until about 1940 , when today's cooler/moist climate became established (Denton and Porter, 1970).

Widespread sedimentation has occurred along with eruption of basalt lava flows during the late Tertiary and Quaternary history of ESRP subsidence. Borehole data show that sediment makes up as much as $50 \%$ of the accumulated material underlying the central and northeastern INEL. Farther south, INEL boreholes contain lower percentages of sedimentary materials, suggesting that the axial volcanic zone has been a long-lived volcanic highland that received relatively little sediment. Sedimentological analysis of subsurface interbeds contained in RWMC drill cores indicate that these sediments were deposited during periods of cooler glacial conditions similar to surficial sediments at the RWMC: the interbeds are predominately silty deposits of fluvial and eolian origin (Hughes, 1993).

Quaternary surficial deposits of the INEL area (Figure 7) include alluvial sediment (gravel, sand, and silt) that has accumulated along major stream channels such as the Big Lost River, alluvial fans adjacent to the ranges north and northwest of INEL, lacustrine deposits of pluvial Lake Terreton, and widespread eolian deposits that include loess (windblown silt) as well as northeast-trending longitudinal dunes of fine sand derived by deflation of sediments from the dried floor and shorelines of Lake Terreton. Loess entirely or partially covers much of the basalt lava flows of the INEL area, forms blankets up to several meters thick on the oldest lava flows, and is thin to absent on young lava flows. In most places on the ESRP, rugged, hummocky lavaflow surfaces are blanketed by deposition of loess that generally makes the terrain smooth. Intermittent lakes and ponds have developed in many closed depressions on the lava flows, resulting in the deposition of fine silt and clay and producing small, flat-floored playas (Nace et al., 1975).

Glaciation and related processes in the northern Rocky Mountains probably began during the late Pliocene or earliest Pleistocene epoch. Alpine glaciers intermittently occupied the mountains of central Idaho in three to four documented advances. At least two extensive montane ice caps occupied much of the Yellowstone Plateau until about 12,000 years ago. The first glacial record 
in Yellowstone is evidenced by a till deposited 1.6 to 2 million years ago, and there is evidence of at least ten glacial advances during the past 1.5 million years (Richmond, 1986).

Three episodes of glaciation have been documented and assigned relative ages in the Pioneer Mountains of central Idaho (Evenson et al., 1982). The two youngest have well-documented multiple moraine complexes, differentiated through the use of moraine morphology, landscape position, soil development, and locations of outwash terraces. The oldest is based on the occurrence of isolated, high gravels of assumed glacial origin. The glaciations are assigned to the Idaho Glacial Model, which was suggested for use as a regional standard for time-stratigraphic correlation. The Idaho Glacial Model and the Rocky Mountain Glacial Model (Mears, 1974) are tentatively correlated on the basis of research in other central Idaho mountain ranges (Williams, 1961; Schmidt and Mackin, 1970; Knoll, 1977; and Colman and Pierce, 1981) as follows: the Potholes glaciation with the Pinedale [20,000 years before present (BP)], the Copper Basin glaciation with the Bull Lake (140,000 years BP), and the Pioneer glaciation (oldest) as pre-Bull Lake in age (Evenson et al., 1982).

The glaciers occupying drainages in the Pioneer mountains dammed the canyon of the East Fork of the Big Lost River creating the Glacial Lake East Fork. This ice-dammed lake formed at least twice, once during the Copper Basin Glaciation (Bull Lake equivalent, 140,000 years BP) and once during the Potholes glaciation (Pinedale equivalent, 20,000 years BP) (Evenson et al., 1982). This ice-dammed lake is the proposed source for catastrophic outburst floods along the . Big Lost River drainage (Rathburn, 1989, 1991, 1993). The oldest documented lake-stand (Copper Basin) predated the emplacement of the 95,000-year-old Quaking Aspen Butte basalt flow, which forms the rim of the RWMC basin on the north and west sides, and therefore did not impact surficial sediments now in place at the RWMC. However, at least one ice-dammed lake in the drainage catastrophically drained during the Potholes glaciation, creating the erosional and deposition features mapped by Rathburn $(1989,1991,1993)$. This flood event has been dated at 20,500 calibrated years BP using cosmogenic ${ }^{3} \mathrm{He}$ and ${ }^{21} \mathrm{Ne}$ from flood-deposited boulders and . scour features (Cerling et al., 1994). Modeling of the flood flows using step-backwater techniques coupled with the geologic evidence indicates a peak discharge of 2 to 4 million cfs. This discharge would have submerged the RWMC under 50 to $60 \mathrm{ft}$ of water. Topographic lows such as the spreading areas west of the RWMC, the RWMC basin, and an area southeast of the Central Facilities Area stored large volumes of flood water, thus attenuating the peak discharge along the main river channel (Rathburn, 1991). Although flood waters broke through the Quaking Aspen Butte basalt flow and created the wind gaps, there is no evidence of erosion of bottom sediments. However, sediments in higher elevations and convex land positions may have been eroded during this event. Limited evidence within the RWMC basin suggests that multiple flooding events occurred near the end of Pinedale glaciation (Dechert et al., 1993).

There is no evidence of glaciation on the ESRP itself; however, the ESRP sediments record the effects of regional glaciation, i.e., widespread loess deposition (Forman et al., 1993), more energetic fluvial activity (Hughes, 1993), glacial outburst floods (Rathburn, 1993), mounded microtopography, and the expansion of pluvial lakes in the Great Basin (Benson and Currey, 1990). It is also inferred that higher stream flows and greater sediment supply from the glaciated mountains led to the growth of large alluvial fans at the mouths of steep canyons on the western and northwestern parts of INEL (Figure 7) (Pierce and Scott, 1982). 


\section{RWMC PHYSIOGRAPHY AND GEOLOGY}

\subsection{Topographic Setting}

The RWMC occupies a small basin of about $2.6 \mathrm{~km}^{2}$ in the southwest part of the INEL (Figures 8 and 9). The basin floor is at an approximate elevation of $1,528 \mathrm{~m}$ and is highly altered by radioactive waste disposal operations. The basin floor is 6 to $12 \mathrm{~m}$ lower than the surrounding terrain. Basalt encircles the basin at elevations up to $1,546 \mathrm{~m}$ within $1.6 \mathrm{~km}$ of the RWMC. To the south of the RWMC, the sediment-covered basalt rises gently to the 1,534 to $1,537-\mathrm{m}$ elevation of a broad, playa-like drainageway (the spreading areas), which extends 6 to $8 \mathrm{~km}$ to the base of the alluvial fan that drains the northwest slopes of Big Southern Butte. The southwestern to northwestern side of the RWMC basin reaches an elevation of $1,546 \mathrm{~m}$ and is formed by the margin of a 100,000-year-old lava flow from Quaking Aspen Butte, a large basaltic shield volcano to the southwest (Figure 10) (Kuntz et al., 1990). The spreading areas lie to the west of this lavaflow margin. There is no natural topographic barrier to surface water incursions into the RWMC basin from the Big Lost River or from the system of channels and playas draining the northwest slope of Big Southern Butte during extreme flooding events (Dechert et al., 1993).

\subsection{Drainage and Flood Control}

The Big Lost River channel approaches the north end of the spreading areas, then turns and flows northeasterly. A diversion dam and a man-made channel between the river and the northernmost spreading area (Spreading Area A) were built to control the direction of river discharge. There is no clearly delineated natural connection between Spreading Area $A$ and Spreading Areas B, C, and D; however, a man-made channel was built for this purpose. A dike has been built along the east-northeast edge of the spreading areas to ensure that water does not encroach into the RWMC basin. Hydrologic modeling of RWMC basin flooding was completed using a worst-case scenario of a Mackay Dam failure coupled with the 1965 Big Lost River flood. (The 1965 flood resulted from a record snowpack in the Big Lost River drainage basin. A record

high stream flow of $1,800 \mathrm{ft}^{3} / \mathrm{sec}$ was recorded and water was diverted into the spreading areas for 9 months.) A second model used the maximum water surface elevation in Spreading Area B to model several types of breaches in Dike 2. The result of the study showed that the berm around the Subsurface Disposal Area (SDA) would be overtopped under the most extreme case investigated (Martineau et al., 1990).

The natural surface-hydrologic outlet of the RWMC basin is to the northeast, along the current Adams Boulevard access road. This drainage, at about the 1,520.5 to 1,528-m elevation, has been graded and channelized to maximize runoff for flood control measures. In the 6 to $8 \mathrm{~km}$ between the RWMC basin outlet and the Big Lost River, elevations gently decrease to about $1,516 \mathrm{~m}$.

\subsection{RWMC Subsurface Geology}

The general geohydrologic framework of the RWMC is described in Barraclough et al. (1976). The subsurface-geologic history of the RWMC area has been constructed using boreholegeophysical logs (Anderson and Lewis, 1989) and the geochronometry and paleomagnetic 


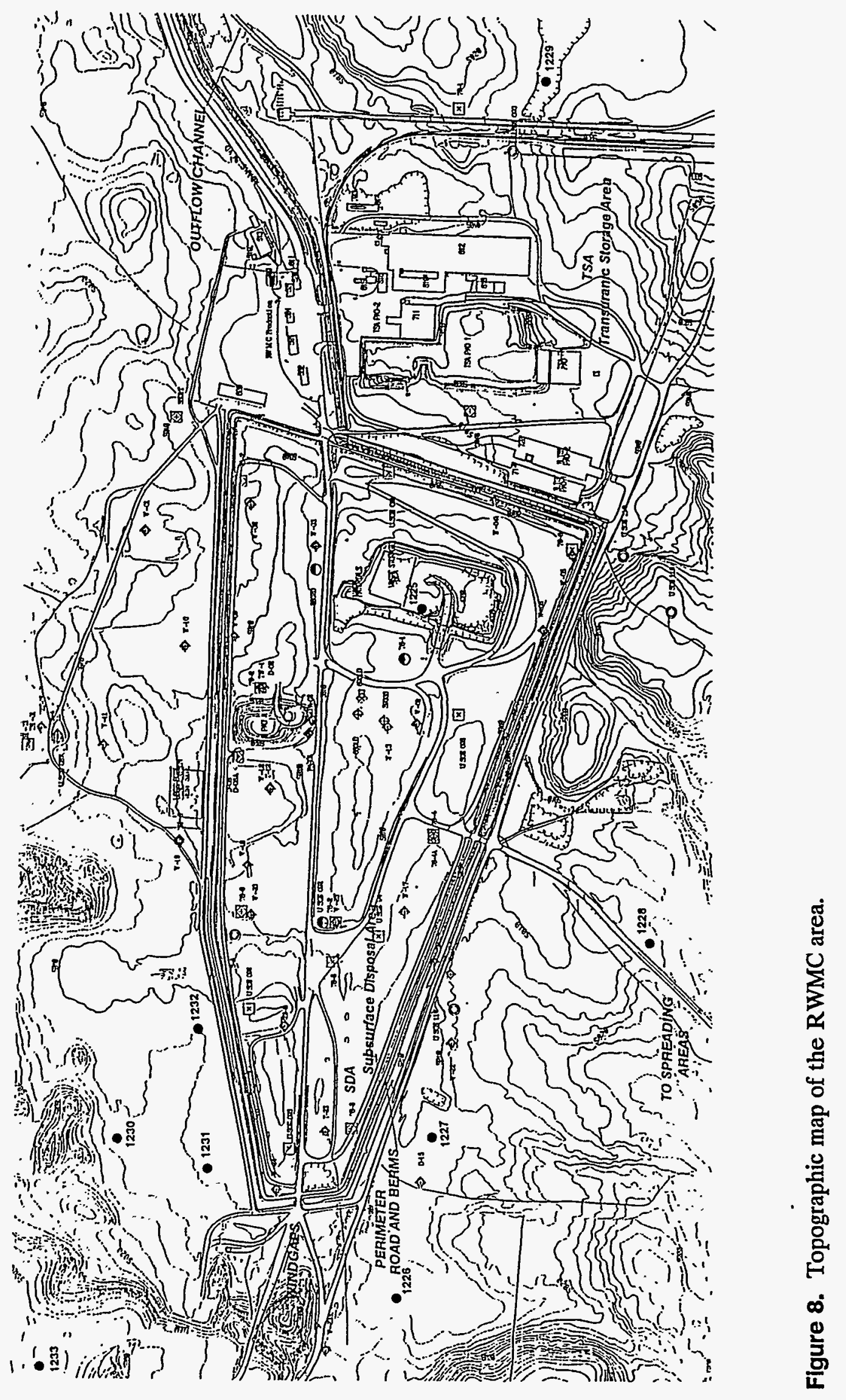




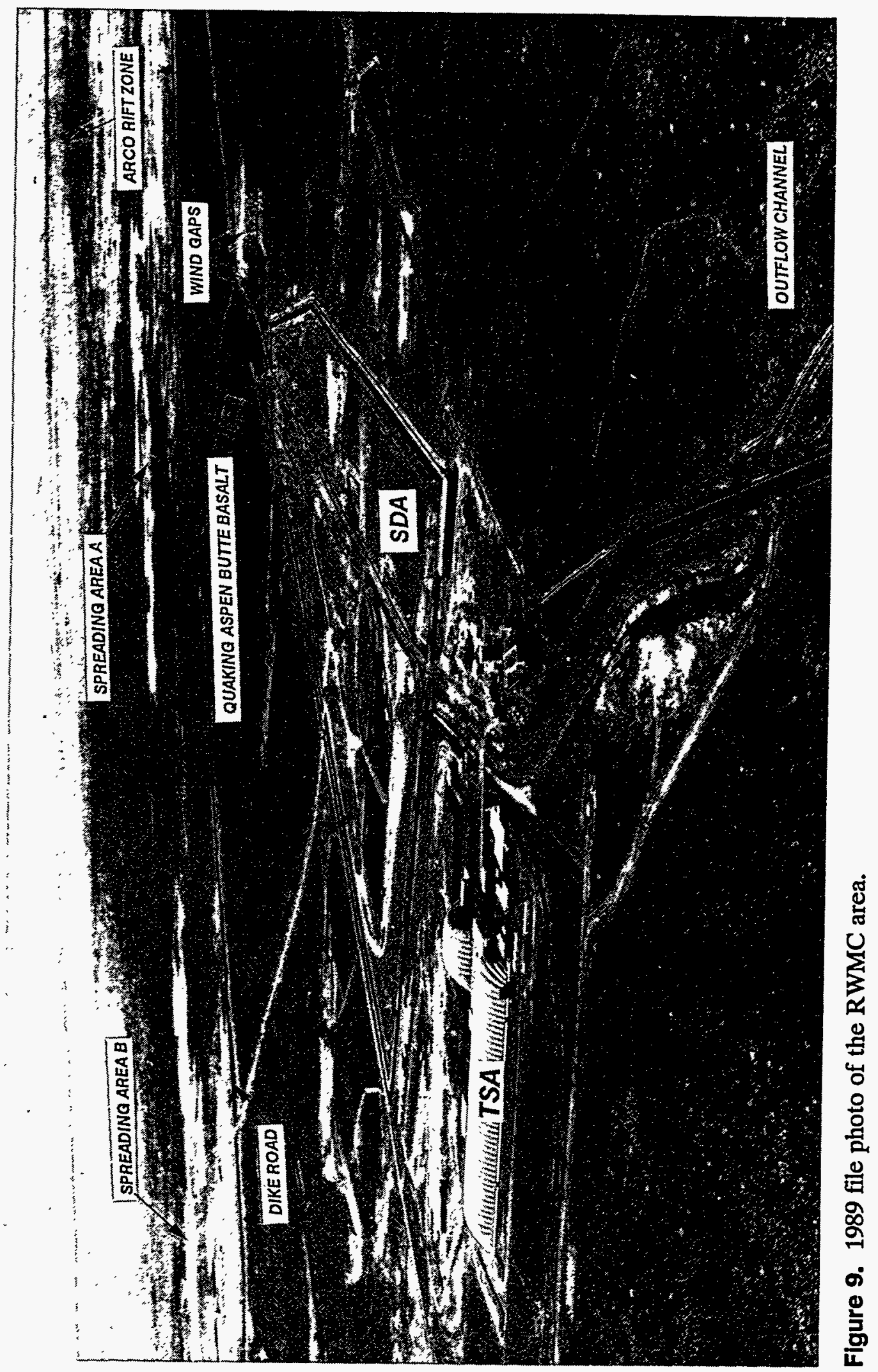


properties of subsurface basalt cores (Champion et al., 1988). RWMC basaltic-lava flows range in age from 100,000 years (surface flows) to more than 500,000 years. (lava flows in boreholes), and occur in lava-flow groups that are separated by major sedimentary interbeds (Figure 11). Paleomagnetic data indicate that the lava-flow groups were emplaced during relatively brief periods of several thousand to several tens of thousands of years, whereas the interbeds were each deposited during lengthy periods of relative volcanic quiescence $(100,000$ years or longer): No conclusive evidence has yet been found from the RWMC subsurface to suggest major deformation of basalts and sediments, or the presence of subsurface unconformities (periods of erosion, during which a part of the stratigraphic record was removed). Rather, the RWMC is situated within an area of regional súbsidence, involving the accumulation of basalts and sediments for at least 4 million years. The average rate of accumulation of INEL basalts and sediments can be derived by compiling the depths and ages of subsurface lava flows from several boreholes (Figure 12). The results from RWMC suggest several periods of volcanic accumulation, separated by several 100,000 -year intervals of quiescence, but the overall rate of accumulation (which approximates the subsidence rate) at RWMC is about $1 \mathrm{ft} /$ thousand years or $0.3 \mathrm{~mm} / \mathrm{yr}$. The $0.3-\mathrm{mm} / \mathrm{yr}$ accumulation rate at RWMC is comparable to that of New Production Reactor Site E, and these results are similar to the long-term subsidence rate of $0.5 \mathrm{~mm} / \mathrm{yr}$ for the entire ESRP.

Hughes (1993) uses the sedimentologic properties of core materials to interpret the depositional environments of three major RWMC interbeds, deposited between approximately $100,000$ and 450,000 years ago. The $30-\mathrm{ft}$ interbed is thin ( 0.3 to $1.5 \mathrm{~m})$ and discontinuous, consists of fine sand and silt, and represents deposition in a floodplain environment. The 110-ft interbed ranges in thickness from 0.6 to $10 \mathrm{~m}$, consists mostly of sand and gravel, and represents deposition on a braided-floodplain with channel systems up to $305 \mathrm{~m}$ wide between topographic highs in the underlying basalt. The 240 - $\mathrm{ft}$ interbed is up to $9 \mathrm{~m}$ thick, consists primarily of sand and silt, and represents deposition in low-energy channels and floodplains that aggraded and entirely covered the underlying basalt in the RWMC area. Sediments comprising the three interbeds may have been deposited from meltwaters associated with retreating Pleistocene glaciers.

\subsection{RWMC Surficial Geology}

\subsubsection{Quaternary Geology}

Quaternary age (past 2 million years) processes in the RWMC area have strongly affected the basin stratigraphy and geomorphic features evident in the surface and near-surface. The surficial sediments were deposited partly in response to glaciation of the northern mountains and the Yellowstone Plateau. This was a time of increased effective precipitation providing sediment that was transported by wind and fluvial systems and deposited as loess, alluvium, slope wash, and playa deposits. Details of the Quaternary stratigraphy are presented in Section 4.3.2.

The rim of the Quaking Aspen Butte basalt, on the west side of the RWMC basin, is breached by two wind gaps. The bottom elevations of the gaps cannot be determined due to anthropogenic changes (filling and road building). East-trending trains of basalt cobbles and boulders up to $1.5 \mathrm{~m}$ in diameter extend from these gaps, 75 to $100 \mathrm{~m}$ into the basin. These gaps and boulder trains are probably the result of late Pinedale glacial outburst flood(s) from the 
Figure 10. Geologic map of RWMC and surrounding areas. Abbreviations on the map refer to dating methods and chronologic indicators and can be interpreted as follows: $\mathrm{K}=$ Potassium/Argon method; $\mathrm{TL}=$ Thermoluminescence method; $\mathrm{GPC}=$ Geologic and Paleomagnetic Correlation method; $\mathrm{C}=$ Radiocarbon method; $\mathrm{Ka}=1,000$ years; my $=$ million years; $(N)$ = Normal paleomagnetic polarity, $(R)=$ Reverse paleomagnetic polarity. 


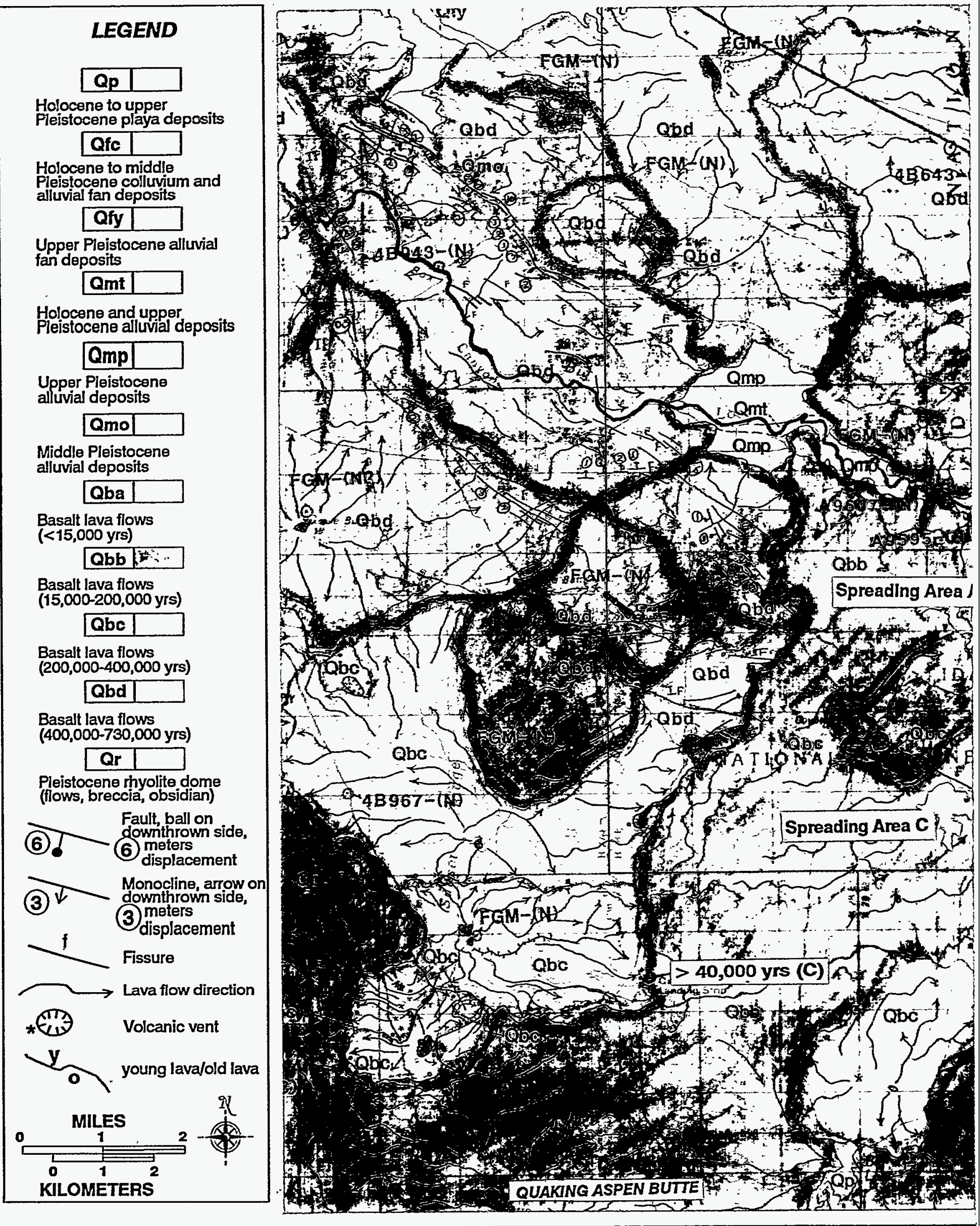




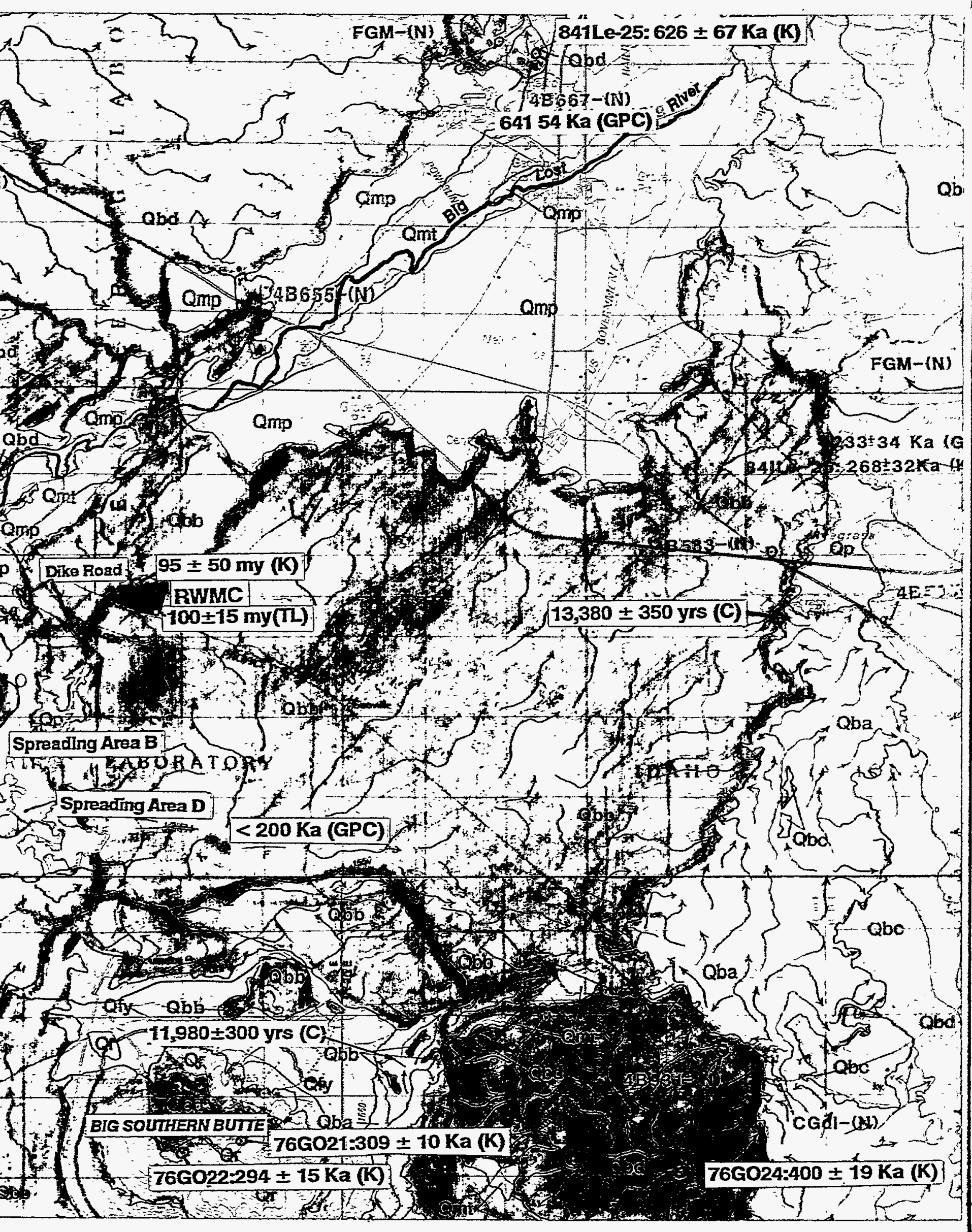




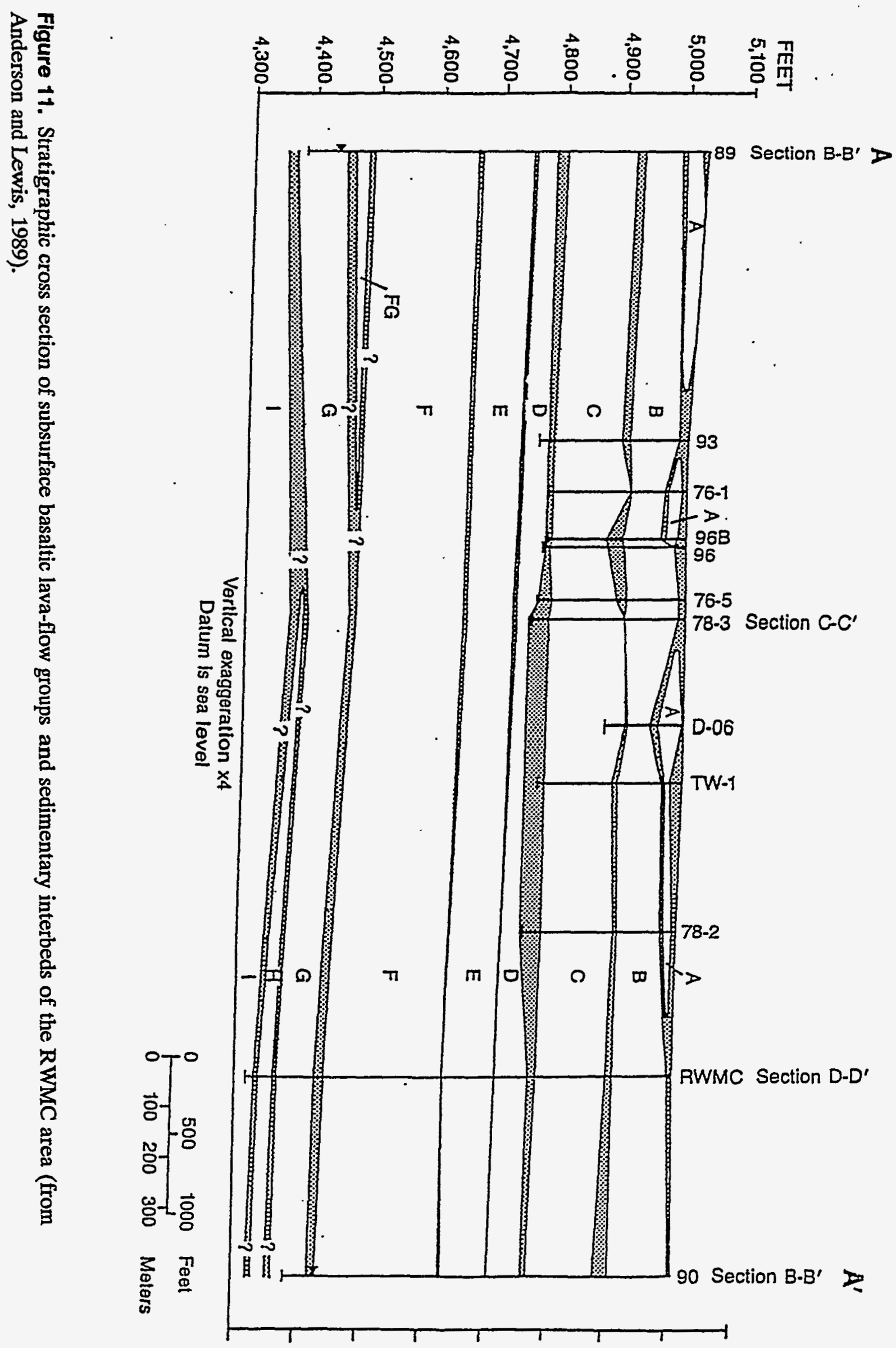




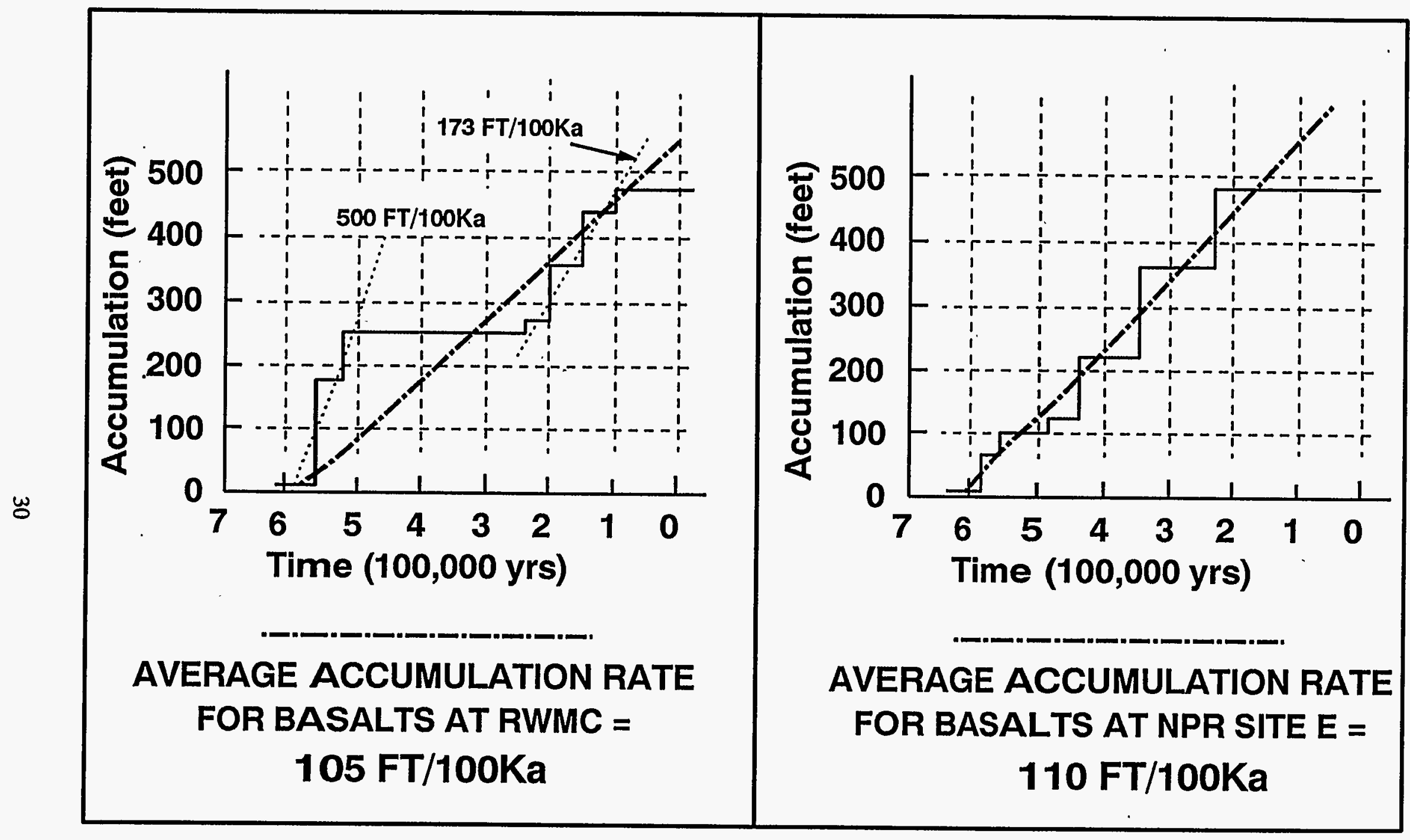

Figure 12. Depths and ages of lava flows in INEL boreholes (data from Champion et al., 1988); best-fit slopes show accumulation rates of basalts and sediments during about the past 600,000 years beneath the southern INEL. 
Pioneer Mountains of central Idaho. The floods are indicated by erosional and depositional features in a wide plain north of the spreading areas and near the present channel of the Big Lost River (Rathburn, 1989, 1991). Rathburn (1991) identifies the upper elevation for flood effects around the RWMC to be 1,539 to 1,542 m. Glacial-outburst flooding has stripped the loess cover from most of the convex and exposed land surfaces, and erosion of later loess from these exposed upland positions has produced large areas of relatively bare basalt. Within the RWMC basin, these eroded surfaces are all above elevations of 1,540 to $1,543 \mathrm{~m}$. All surfaces below the 1,530-m elevation within the RWMC basin, including the RWMC itself, are accumulating sediments (Dechert et al., 1993).

Although the timing and number of glacial-outburst flood events affecting the RWMC area are poorly known, Rathburn (1991) gives evidence for more than one flood. The RWMC wind gaps and boulder trains suggest very high-energy conditions, while the stripping of loess only from convex and exposed land surfaces suggests a much less energetic event. Data from the RWMC area therefore may be best explained by a strong, mid-to-early Pinedale glacial-outburst flood, followed by a period of Pinedale loess deposition and then a weak, late-Pinedale glacial-outburst flood that stripped the loess in the pattern noted above. The earlier, high-energy event has been dated at 20,500 calibrated years BP using cosmogenic helium and neon (Cerling et al., 1994). The later, lower-energy event probably occurred around 10,000 to 12,000 years ago at the end of the Pinedale glaciation (Dechert et al., 1993).

Features indicating surficial movement and deposition of sand, although not observed in the RWMC basin, are seen immediately west and north of RWMC on the glacial-outwash plain and the Quaking Aspen Butte basalt. The fine sands are dark colored, and are probably derived from lava flows and young tephra cones to the west of the RWMC. The sand is mixed into the surficial loess, and forms dunes where it is trapped by vegetation. Some of the sand dunes have barchan-like shapes, and although now vegetated and apparently stabilized, may be relics of a windier or drier climate. Within the RWMC basin, the main effects of this Holocene wind activity are mixing of sand into the surface loess, producing a sandy-loess blanket on the lee side of the western-basin margin that is thicker than the loess found in other landscape positions.

Undisturbed parts of the RWMC basin and much of the INEL exhibit a mounded microtopography. The mounds range in size up to $10 \mathrm{~m}$ in diameter and $0.5 \mathrm{~m}$ high. They occur on both flat and sloped topographic surfaces. The mounds formed by a frost heave process, caused by the growth of segregated ice lenses during intense seasonal freezing and thawing. They formed during the latest Pleistocene or early Holocene, after glacial outburst flooding, but prior to Holocene soil development. They have been sites of long-term and repeated activity by burrowing mammals. Although they have been modified by ongoing surficial processes, their presence on certain parts of the landscape indicate a relative lack of large-scale erosion.

There is a consistent pattern of plant pedestalling within the RWMC basin and most of the surrounding area. Plants on upland, sideslope and convex positions generally exhibit pedestals 6 to $8 \mathrm{~cm}$ high, but plants in low-lying, concave positions exhibit very little edestalling. This pattern is common in desert environments and indicates the extent of erosional processes resulting from present climates. In the area surrounding the RWMC basin, surficial sediments (mainly loess) have apparently been recently deflated by about $8 \mathrm{~cm}$. 


\subsubsection{Quaternary Stratigraphy}

Surficial deposits in the region around the RWMC are shown on Figure 10. Much of the present land surface is underlain by wind-blown silt (loess) of varying thickness. North of the RWMC is the channel of the Big Lost River, surrounded by a wide belt of Upper Pleistocene mainstream alluvium that was deposited toward the end of the last glacial period, a time of increased discharge and sediment supply. The smaller, postglacial river has incised its older materials, and has deposited Holocene mainstream alluvium. Pleistocene alluvial-fan deposits surround Big Southern Butte, a 300,000-year-old rhyolite dome to the south of RWMC. Several Holocene basalt lava fields occur $10 \mathrm{~km}$ southeast of RWMC, erupted from vents of the Arco volcanic-rift zone and the axial volcanic zone.

The surficial deposits within the RWMC basin range in thickness from zero to more than $23 \mathrm{ft}$, reflecting deposition on the irregular surface of underlying basalts (Rightmire and Lewis, 1987). Consistent with the rest of the ESRP, the RWMC basin is at least partly covered by a blanket of loess, except where it has been removed by glacial-outburst floods. Two distinct loess deposits have been documented in the basin resting on the 100,000-year-old basalt lava of Quaking Aspen Butte (Forman et al., 1993) (Figures 13 and 14). The two loess deposits yield thermoluminescence age estimates of $28,000 \pm 3,000$ years (loess " $A$ ") and 74,000 $\pm 6,000$ years (loess "B"). Regional geochronology indicates that the latest period of loess deposition occurred in several pulses beginning about 40,000 to 35,000 years ago, ending about 10,000 years ago. These pulses span an entire glacial/deglacial cycle, and are generally coincident with a period of regional pluvial-lake expansion and Pinedale glaciation. The older loess is estimated to have been deposited 80,000 to 60,000 years ago, and may be correlative with a documented early Pinedale glaciation and a high stand of pluvial lakes in the Great Basin (Forman et al., 1993). Data on the physical and chemical characteristics of the older loess unit indicate that it is not regionally correlative to a buried loess (interpreted to be of Bull Lake age) mapped on the margins of the ESRP by Pierce et al. (1982). Details on the regional stratigraphy of buried loess units remain to be worked out.

Eleven soil sites on and around the RWMC were excavated and fully described in order to obtain data on the distribution, physical properties, and geochemistry of surficial soils in the RWMC basin (Dechert et al., 1993) (Figures 15 and 16). Most of the sites sampled are in predominately silty materials, and particle-size analyses generally lead to the identification of siltloam and silty clay-loam textural classes. Loess A mantles most of the RWMC landscape below elevations of 1,530 to $1,531 \mathrm{~m}$, and most RWMC soil sites contain 80 to $100 \mathrm{~cm}$ of loess A; this likely represents the original thickness because there is no evidence of significant loess movement out of the RWMC basin. Soil sites on higher elevations and exposed landscape positions around the basin are missing up to $50 \mathrm{~cm}$ of the loess A sequence found in the bottom of the basin (Dechert et al., 1993). This sediment has likely been redistributed downslope by slope wash and/or soil creep, or removed by eolian entrainment.

Soils developed in loess $A$ and the overlying slopewash sediments generally exhibit an A-Bw-Bk horizon sequence, consisting of a surface horizon with higher organic content (A), a second horizon showing soil structure or color development but little accumulation of illuvial material $(\mathrm{Bw})$, and a third horizon that has accumulated calcium carbonate (Bk). This sequence is typical of loess soil development on the ESRP during the last 10,000 to 15,000 years (Lewis and 


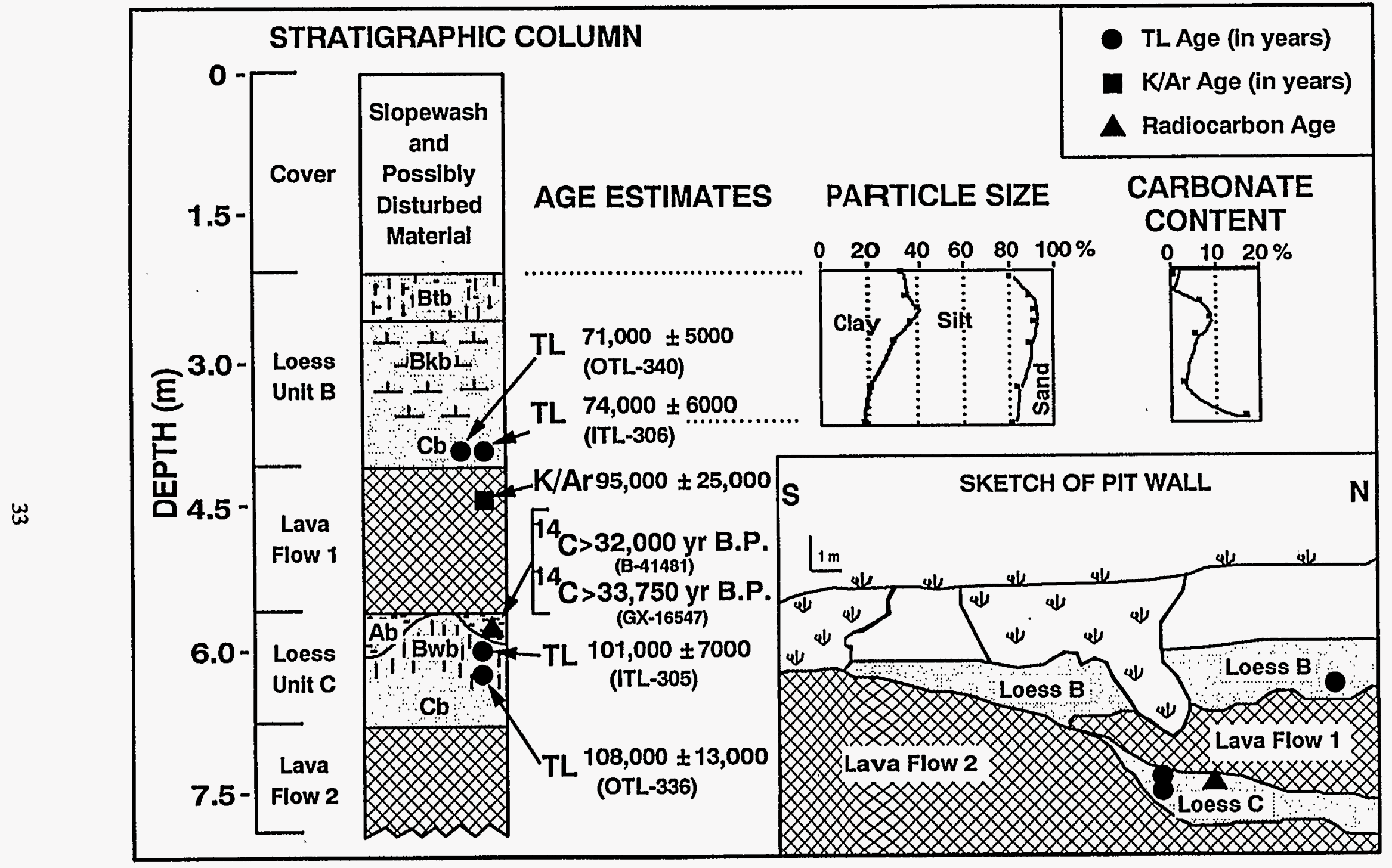

Figure 13. Stratigraphy, age estimates, particle-size distribution, and carbonate content of loess and basaltic lava flows exposed in the west wall of an RWMC open pit (adapted from Forman et al., 1993). K-Ar age (1-sigma error) for the uppermost flow is from corehole 77-1, about $550 \mathrm{~m}$ north of the RWMC pit (Champion et al., 1988). Vertical lines and crossed lines represent the limits of the Bw and Bt horizons, respectively. 


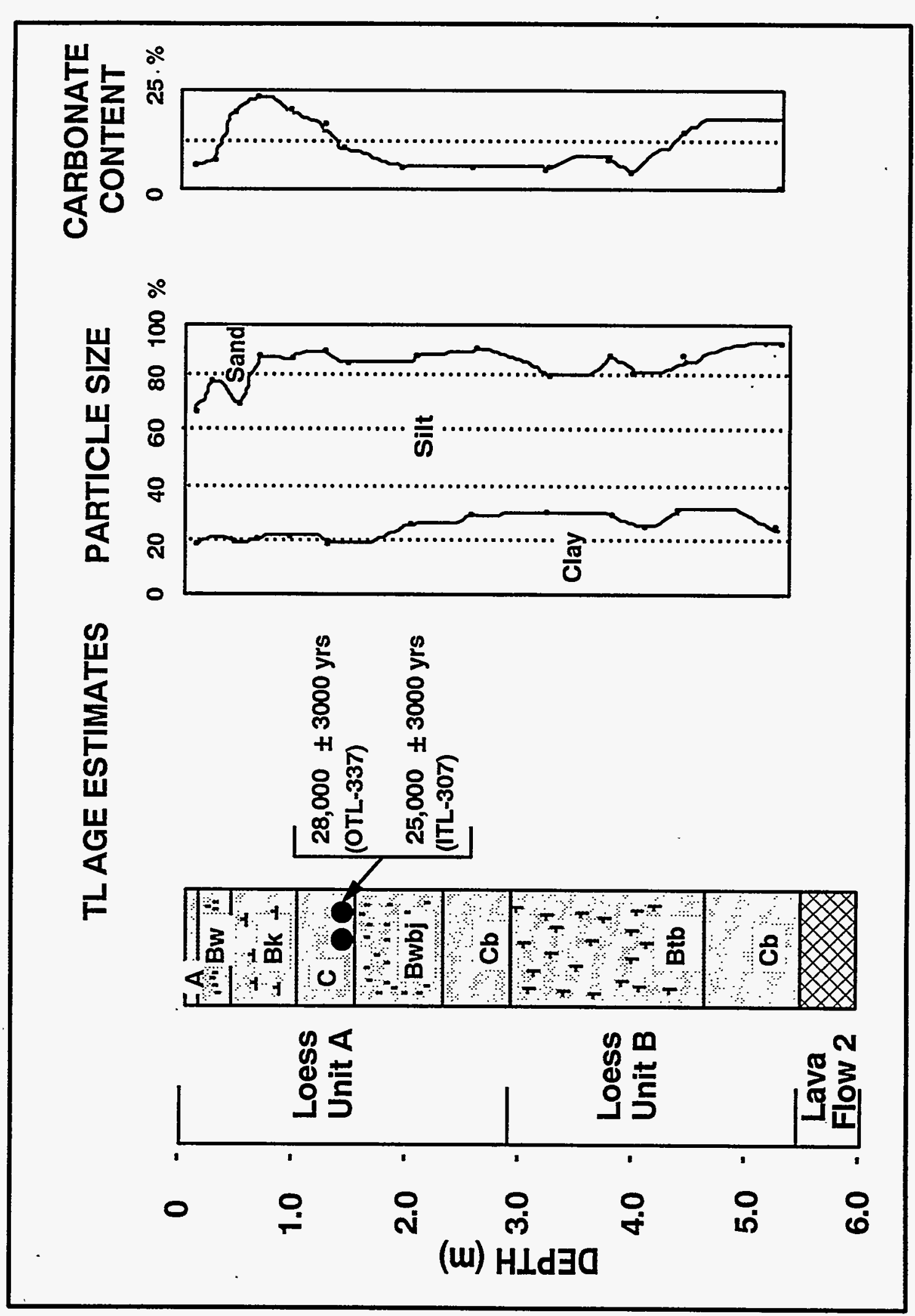

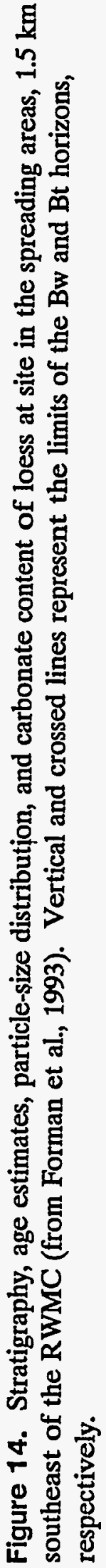




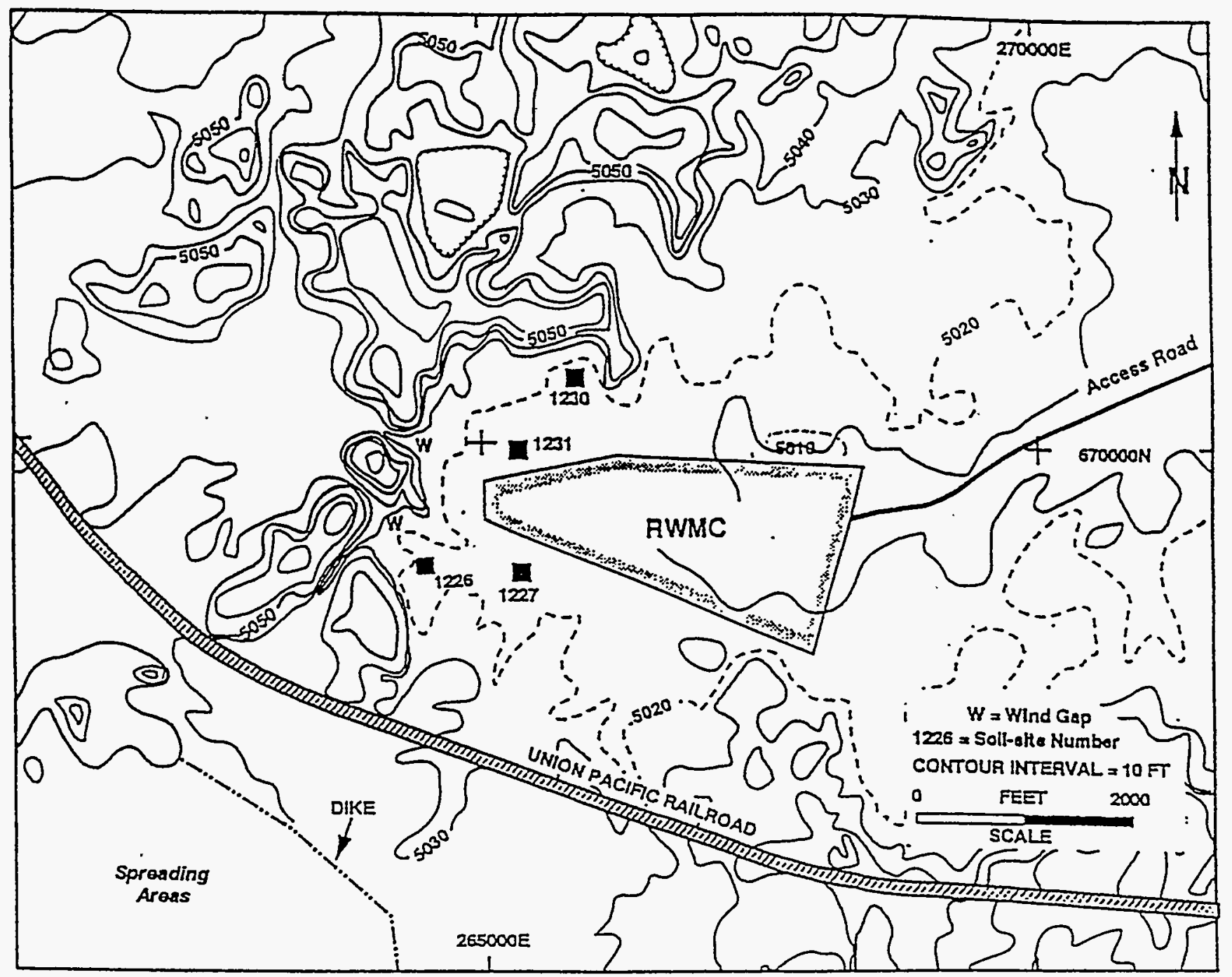

Figure 15. Index map of the RWMC basin, showing the locations of selected soil sites (from Dechert et al., 1993). See Figure 16 for soil profiles and stratigraphic relations at these sites. 
Fosberg, 1982). Sites 1226,1227 , and 1230 are representative of the deep sedimentary deposits on the RWMC basin floor, with surface soils ranging from 96 to $165 \mathrm{~cm}$ in depth (Figures 15 and 16). All three sites contain several horizons that have been enriched with sand and clay. Increased sand is likely an eolian contribution, and increased clay is probably derived by slopewash from the surrounding basin margin.

The buried soils within the basin are developed in materials deposited after the Bull Lake glaciation and prior to deposition of the overlying loess $\mathrm{A}$. Thermoluminescence dating and other analyses indicate that these paleosols formed during earliest Pinedale glaciation (12,000 to 75,000 years), but postdate the Quaking Aspen Butte basalt (100,000 years). As mentioned above, the sediments in which the buried soils developed have a controversial origin. A strongly developed soil complicates interpretation of the depositional environment of the sediment. High electrical conductivity values indicate that the buried soils have accumulated salts, probably before they were covered by loess A. Textures of the paleosols are predominately silty clay loams and heavy silt loams. The clay contents are significantly higher than those of unaltered loess found on the ESRP, suggesting at least two interpretations. One is that the buried soils may have developed in more clay-rich sediments, i.e., deposition in a playa within a closed basin surrounded by lava flows. Alternatively, the clay contents of the paleosols may be attributable to a long period of weathering and soil-forming processes that increases clay content due to translocation. In the latter case, the textures of the soil would indicate deposition as primary loess. Despite apparent difficulties in stratigraphic interpretation, the overall evidence indicates that the RWMC basin has been the site of long-term aggradation with little erosion.

All eleven of the trenched sites exhibit a rock line at the contact between the buried soils and surficial soils. The rocks are dominantly gravel- to cobble-sized, subangular basalt (Figure 16) and were probably deposited on a paleosurface by tributary flooding of the Big Lost River. At site 1227 , the rock line is embedded in platey-structured, possibly water-deposited material. A TL date of 14,100 to 14,800 years on sediments overlying the rock line can be interpreted as a minimum age for the paleosurface on top of the buried soils.

The work by Dechert et al. (1993) and shallow augering and sampling of surficial sediments at the RWMC by Hubbell et al. $(1985,1987)$ indicate that much of the sediment overlying loess $A$ in the RWMC basin has been reworked by local slope-wash processes. However, the potential role of surface water from the Big Lost River and Big Southern Butte drainages must also be considered. In Spreading Area A, Holocene fluvial deposits overlie the Pinedale glacial-outburstflood gravels, indicating that postglacial Big Lost River flood waters inundated the northernmost spreading area and parts of the basalt-floored flats to the west of RWMC. However, there is no evidence that any of these Holocene floods entered the southern spreading areas or beyond. While it cannot be verified today because the wind gap on the western margin of the RWMC basin has been filled, the 1976 Arco Hills SE quadrangle indicates that the floor of the wind gap was 1,531 to $1,537 \mathrm{~m}$ in elevation. It is therefore possible that large, Holocene floods of the Big Lost River could have inundated the RWMC basin and may account for thin, discontinuous lenses of sand and gravel found within the surficial sediments (Hubbell et al., 1985; 1987) and the surficial pebble lag noted in sites near the windgaps (Dechert et al., 1993). These floods appear to have lost sufficient energy by the time they entered the RWMC basin to cause deposition of the transported load rather than erosion of surficial sediments in the basin. 


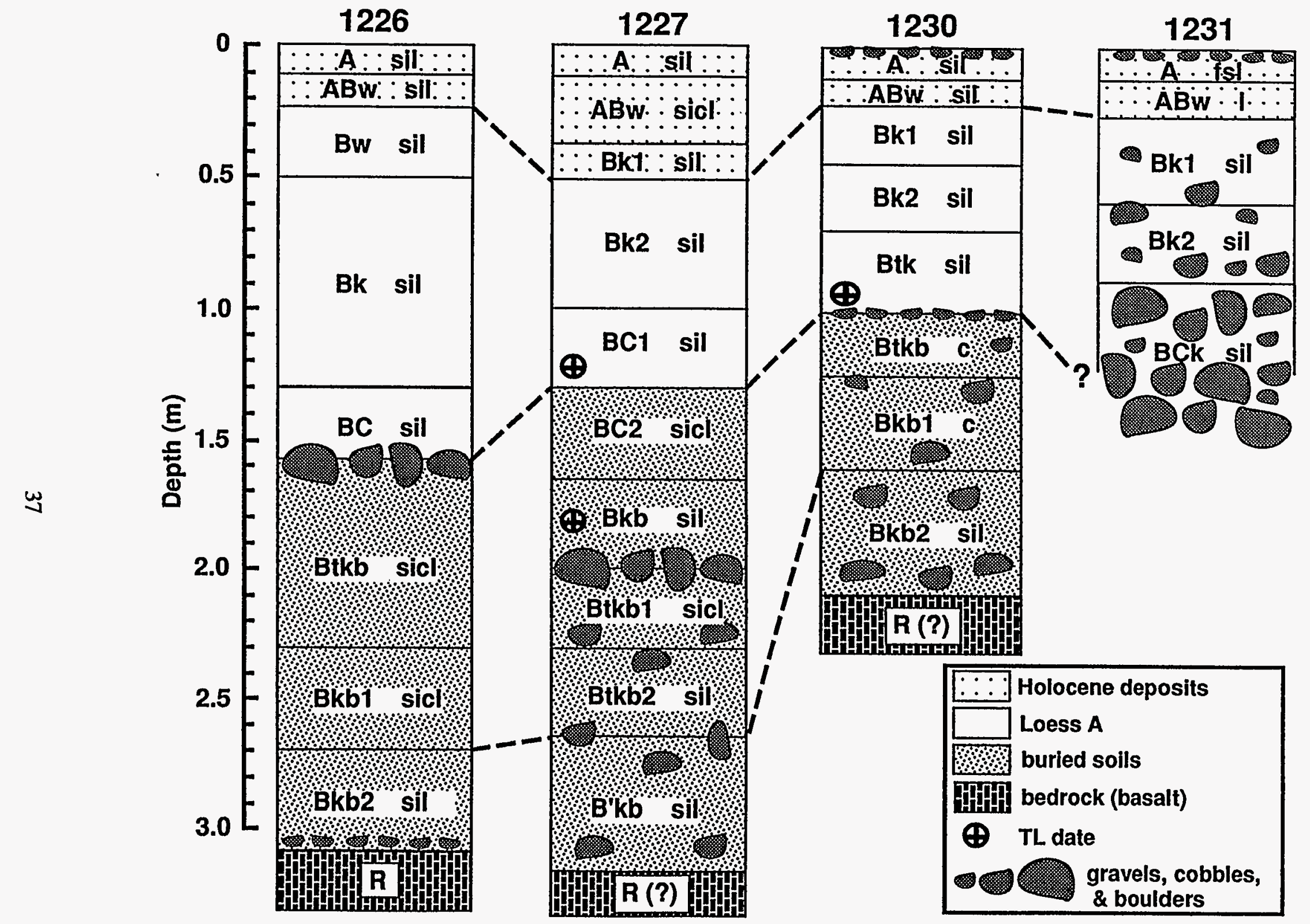

Figure 16. Soil profiles and stratigraphic relations between soil sites of the RWMC basin (from Dechert et al., 1993). 


\subsubsection{RWMC Archaeology}

The RWMC area contains much evidence of prehistoric human occupation; archaeological artifacts, which date back 10,000 years or more, are present at the surface. The oldest materials are stone projectiles known as Folsom points, which have been recovered together with production flakes from a surface site at the base of the basalt ridge to the west of RWMC. What is interesting and relevant about these sites and their contents is that materials dating from 10,000 years BP appear on the ground surface, together with much younger cultural materials only a few millennia or centuries in age. Many sites are relatively fragile in both content and relationship of components, and their in situ preservation indicates that archaeological materials have not generally been affected by the soil-forming processes that are typical of more-humid climatic regimes. The main causes of site disturbance through time appear to be biological, involving burrowing insects, mammals, and plant roòts (Personal communication with Miller, 1993).

Excavation of a site near the northern RWMC perimeter fence (Ringe, 1992) uncovered no artifacts below $30 \mathrm{~cm}$, the depth to the caliche or Bk horizon that is typical of ESRP surficial soils. Archaeological materials on the surface suggested that the site had been periodically reoccupied, but not intensively. The occupations occurred infrequently during a long time span of the Middle Prehistoric period (ca. 5,000 to 1,300 years BP), as indicated by diagnostic projectile points, including Humboldt lanceolate (ca. 5,000 to 35,000 years BP) and Elko corner-notched (ca. 3,500 to 1,300 years BP) dart points.

Archaeological observations that support the long-term stability of the ESRP land surface and the periodic protection of artifacts by sediment cover include (a) the preservation and exposure of perishable site components such as bone, burned bone, shell, and hearths with charcoal; these materials cannot survive long-term surface exposure; (b) lithic flakes and artifacts from sites of varying ages commonly exhibit calcium-carbonate coatings, especially on their undersides, suggesting long-term burial and re-exposure; and (c) some lithic debris displays exposed-side polish or patina, which is a result of wind abrasion.

Evidence from the INEL and elsewhere on the ESRP therefore suggests that archaeological materials have been largely unaffected by erosional or soil-forming processes during the past 10,000 years. Repeated covering and uncovering of the materials by eolian sediment (predominately fine sand) suggests that ESRP Holocene erosion and deposition has been nearly in net balance on open terrain. The effects of this Holocene eolian erosion and deposition are apparently limited to the upper 1 to 2 decimeters of surficial sediment, because archaeological materials are either maintained at the surface, or are buried to a maximum depth of only $20 \mathrm{~cm}$. 


\section{SUMMARY AND CONCLUSIONS}

A wide variety of information has been considered in assessing the long-term stability of the RWMC landscape: regional tectonics, site-specific volcanology, sedimentation and soils, geochronometry, modern geodetic observations, and the archacological record. In the wake of the Yellowstone mantle plume, the regional ESRP land surface has been subsiding for more than 4 million years, and during the past 600,000 years, the apparent rate of subsidence has been about $0.3 \mathrm{~mm}$ per year. Modern geodetic observations indicate that the ESRP continues to subside, and is therefore likely to remain a structural and topographic basin into the foreseeable future.

During subsidence, the ESRP has received late Tertiary and Quaternary basalts and sediments that have accumulated to a thickness of more than $1 \mathrm{~km}$ at the INEL. Basalts and sediments at. the modern ESRP surface are undergoing minimal erosion, and are likely to be buried by additional material as the ESRP continues to subside. No major erosional unconformities are interpreted from the Quaternary stratigraphic record beneath the INEL. No major canyons or erosional landforms caused by long-term processes (i.e. stream flow) are present on the modern ESRP land surface. Glacial-outburst floods created erosional landforms, but these were shortterm discrete events. ESRP surface drainage is poorly integrated and of low density, reflecting the low rainfall, permeable soils, and bedrock of the region, and the predominate sagebrush steppe vegetation. Overland flow is a relatively unimportant process in comparison with infiltration, and establishment of major drainage patterns is further hindered by the low surficial relief in relation to local base levels (Lost River sinks and Birch Creek playa). The Snake River is aggradational (not erosional) for most of its reach along the southern margin of the ESRP. All of these observations support the idea that the ESRP has been a region of net accumulation for at least the past 4 million years, and continues as such today.

Geologic processes influencing the RWMC area are basaltic volcanism, deposition of finegrained sediment by wind and water, glacial outburst flooding, slopewash processes, and soil formation. The most recent volcanic event at RWMC was the emplacement of the Quaking Aspen Butte lava flow about 100,000 years ago, and quantitative estimates of recurrence of lava flows at RWMC exceeds 100,000 years (corresponding to recurrence probabilities of about $1 \times 10^{-5} / y r$ ). The effects of volcanic processes at RWMC are described by Hackett (1993). Stratigraphy of surficial materials at the RWMC record multiple episodes of late Pleistocene eolian and alluvial sedimentation followed by soil formation. Glacial outburst flooding inundated the RWMC area at least once during the late Pleistocene, eroding the wind gaps in the Quaking Aspen Butte Basalt and removing sediments from upland positions around the basin. Holocene age floods of the Big Lost river deposited lag gravels in the RWMC basin, but resulted in no recognizable erosional landforms. Erosional processes have moved up to $50 \mathrm{~cm}$ of sediment off the slopes and exposed landscape positions around the RWMC basin. Some of this sediment has been redeposited on the basin floor by slope wash and soil creep processes, and some may have been removed from the basin by eolian processes. Archeological evidence indicates that surficial processes active during the Holocene have largely resulted in minor redistribution of the upper 10 to 20 centimeters of sediment by slopewash and eolian processes.

Climate change is an uncertain factor in the future of the RWMC basin, largely because predictions are complicated by incomplete understanding of many factors. Among these are global greenhouse warming, rapid shifts between glacial and interglacial stages, differences in the 
climates of the next-to-last and current interglacial periods, and incomplete understanding of the mechanisms driving climate change. Based on Holocene climate changes, it is likely that future climate shifts will occur. Geologic evidence supports the conclusion that the climate shifts that occurred during the Holocene (Altithermal, Neoglacial) did not cause significant erosion of surficial sediments within the RWMC basin. If climate shifts within the next 10,000 years are on the same order of magnitude as those experienced in the past 10,000 years, no appreciable erosion should occur at the RWMC. A climate shift to a full glacial cycle may result in buildup and emptying of ice-dammed lakes in the Big Lost River headwaters, accompanied by increased discharge of the river itself. Although prehistoric glacial outburst floods and Big Lost River floods did not result in erosion of sediments on the RWMC basin floor, the magnitude, frequency, and response to changes in topography make these events unpredictable.

A brief summary of important geologic processes and our conclusions on the implications for erosion at the RWMC as a result of those processes is given in Table 3. 
Table 3. Implications of erosional processes at the RWMC for the next $10^{4}$ years.

\begin{tabular}{|c|c|c|}
\hline Process & Comments & Conclusion \\
\hline $\begin{array}{l}\text { Seismic } \\
\text { events }\end{array}$ & $\begin{array}{l}\text { Earthquake ground acceleration of } 0.3 \mathrm{~g} \text { has a } \\
\text { probability of recurrence of about } 1 \times 10^{-4} / \mathrm{yr} \text { at } \\
\text { the RWMC. Ground motions }>0.5 \mathrm{~g} \text { could be } \\
\text { potentially damaging but have low annual } \\
\text { probabilities of recurrence. (see Section } 2, \mathrm{pg} .5-7 \text { ) }\end{array}$ & $\begin{array}{l}\text { Earthquake ground motion at } \\
1 \times 10^{-4} / y r \text { probability of } \\
\text { occurrence is not considered a } \\
\text { threat to buried waste at the } \\
\text { RWMC. }\end{array}$ \\
\hline $\begin{array}{l}\text { Volcanic } \\
\text { activity }\end{array}$ & $\begin{array}{l}\text { Probability of recurrence of volcanism at the } \\
\text { RWMC is } 8 \times 10^{-6} / y r \text {, and ground deformation and } \\
\text { fissuring would have a lower probability of } \\
\text { recurrence because the RWMC is outside the } \\
\text { zones known to be subject to those effects. (see } \\
\text { Section 2, p. 7) }\end{array}$ & $\begin{array}{l}\text { Volcanism or volcanic } \\
\text { processes are not likely to } \\
\text { contribute to increased erosion } \\
\text { at the RWMC. }\end{array}$ \\
\hline $\begin{array}{l}\text { Slope } \\
\text { processes }\end{array}$ & $\begin{array}{l}\text { Slope processes include slope wash and soil creep. } \\
\text { Both processes have eroded sediment off the } \\
\text { slopes and deposited it on the basin floor } \\
\text { throughout Holocene time. These processes are } \\
\text { ongoing. (see Section } 4.3 .1, \mathrm{pg} .30 \text { and } 35 \text { ) }\end{array}$ & $\begin{array}{l}\text { Slope processes will not result } \\
\text { in removal of sediment from } \\
\text { the RWMC basin floor. }\end{array}$ \\
\hline $\begin{array}{l}\text { Eolian } \\
\text { processes }\end{array}$ & $\begin{array}{l}\text { Eolian processes transported and deposited loess in } \\
\text { distinct pulses associated with glacial climates. } \\
\text { Since deposition, wind entrainment has resulted in } \\
\text { the removal of sediment from high elevation and } \\
\text { exposed landscape positions around the RWMC } \\
\text { basin. Wind entrainment can increase with a } \\
\text { decrease in vegetational cover brought about by } \\
\text { natural (climate change, wildfires) or man-made } \\
\text { (excavations, etc.) events. (see Section } 4.3 .2, \mathrm{pg} \text {. } \\
29-35 \text { ) }\end{array}$ & $\begin{array}{l}\text { Wind processes have not } \\
\text { resulted in historical erosion of } \\
\text { sediment from the basin floor. } \\
\text { However, any unstabilized, } \\
\text { disturbed area is subject to } \\
\text { increased eolian entrainment } \\
\text { of sediment. This should be } \\
\text { considered in the final cover } \\
\text { design. }\end{array}$ \\
\hline $\begin{array}{l}\text { Local } \\
\text { basin } \\
\text { flooding }\end{array}$ & $\begin{array}{l}\text { Large snow accumulations followed by rapid } \\
\text { snowmelt and runoff have resulted in flooding of } \\
\text { the RWMC basin. These floods cause ponding of } \\
\text { water on the basin floor and surface outflow } \\
\text { towards the Big Lost River. The effects are } \\
\text { possible redistribution of surficial sediments, and } \\
\text { development of incipient rills on the hillslopes. No } \\
\text { specific studies have been conducted on removal of } \\
\text { sediments due to basin outflow, however discharge } \\
\text { and water velocity are not likely to be of sufficient } \\
\text { magnitude for sediment transport. }\end{array}$ & $\begin{array}{l}\text { Local basin floods are not } \\
\text { likely to remove sediment from } \\
\text { the RWMC basin. They may } \\
\text { result in transport and } \\
\text { deposition of sediments off the } \\
\text { sideslopes onto the basin floor } \\
\text { and/or redistribution of } \\
\text { surficial sediments at very } \\
\text { localized areas within the } \\
\text { basin. }\end{array}$ \\
\hline
\end{tabular}


Table 3. (continued).

\begin{tabular}{|c|c|c|}
\hline Process & Comments & Conclusion \\
\hline $\begin{array}{l}\text { Major } \\
\text { tributary } \\
\text { floods }\end{array}$ & $\begin{array}{l}\text { Flooding of the Big Lost River during the past } \\
10,000 \text { years has resulted in flooding of the } \\
\text { RWMC basin. These floods deposited thin } \\
\text { discontinuous lenses of sand and gravel within } \\
\text { surficial sediments, and a lag of small gravels on } \\
\text { the surface east of the wind gaps, but did not leave } \\
\text { evidence of erosion. These floods are thought to } \\
\text { have been low-energy events. (see Section } 4.3 .2 \text {, } \\
\text { pg. } 35\end{array}$ & $\begin{array}{l}\text { Given the present } \\
\text { configuration of the Big Lost } \\
\text { River channel, major tributary } \\
\text { floods are not expected to } \\
\text { result in erosion of sediment } \\
\text { from the RWMC basin. In the } \\
\text { event that the channel } \\
\text { configuration changes such } \\
\text { that the primary flow is } \\
\text { through the wind gaps, channel } \\
\text { incision would result in } \\
\text { significant erosion. Such } \\
\text { channel changes are } \\
\text { considered to have a very low } \\
\text { probability. }\end{array}$ \\
\hline $\begin{array}{l}\text { Glacial } \\
\text { outburst } \\
\text { floods }\end{array}$ & $\begin{array}{l}\text { At least one glacial outburst flood inundated the } \\
\text { RWMC basin under } 50 \text { to } 60 \mathrm{ft} \text { of water at the end } \\
\text { of Pinedale glaciation. The flood eroded the } \\
\text { windgaps and deposited large basalt boulders inside } \\
\text { the basin. Water in the spreading areas and } \\
\mathrm{RWMC} \text { basin was largely ponded, which resulted } \\
\text { in attenuation of the peak discharge along the } \\
\text { main river channel. Glacial outburst floods could } \\
\text { inundate the RWMC basin, but must be preceded } \\
\text { by a return to glacial climatic conditions and } \\
\text { growth of glaciers in the Big Lost River } \\
\text { headwaters area. The current interglacial has } \\
\text { lasted } \approx 12,000 \text { years. The previous five interglacial } \\
\text { periods lasted from } 28 \text { to } 49 \mathrm{ky} \text { (see Section } 4.3 .1 \text {, } \\
\text { p. } 28 \text { and } 29 \text { ). }\end{array}$ & $\begin{array}{l}\text { Inundation by glacial outburst } \\
\text { floods within the next } 10,000 \\
\text { years is unlikely. }\end{array}$ \\
\hline $\begin{array}{l}\text { Climate } \\
\text { change }\end{array}$ & $\begin{array}{l}\text { Climate is very likely to change within the next } \\
10,000 \text { years. If climate fluctuations are within the } \\
\text { ranges experienced throughout the past } 10,000 \\
\text { years, the erosional processes discussed in this } \\
\text { report should not significantly increase sediment } \\
\text { removal from the RWMC basin (see Section } 3.2 \text {, } \\
\text { p. } 18 \text { ) }\end{array}$ & $\begin{array}{l}\text { Within Holocene temperature/ } \\
\text { moisture ranges, there is not a } \\
\text { significant threat of increased } \\
\text { erosion. Outside these ranges, } \\
\text { we cannot predict. }\end{array}$ \\
\hline
\end{tabular}




\section{REFERENCES}

Anders, M.L. and Sleep, N. H., 1993, "Magmatism and Extension: The thermal and Mechanical Effects of the Yellowstone Hotspot," Journal of Geophysical Research, B11, V97, pp. 15,379-15,393.

Anderson, S.R. and Lewis, B.D., 1989, Stratigraphy of the unsaturated zone at the Radioactive Waste Management Complex, Idaho National Engineering Laboratory, Idaho, U.S. Geological Survey Water-Resources Investigations Report 89-4065, 54 p.

Antevs, E.V., 1948, "The Great Basin, with Emphasis on Glacial and Postglacial Times," Bulletin of the University of Utah, 38, p. 168-191.

Barnosky, C.W., Anderson, P.M., and Bartlein, P.J., 1987, "The Northwestern United States During Deglaciation: Vegetational History and Paleoclimatic Implications," North America and Adjacent Oceans During the Last Deglaciation, Ruddiman, W. F. and Wright, H. E., Jr. (eds.), Geological Society of America, Boulder, CO, p. 289-321.

Barry, R.G., 1983, "Late Pleistocene Climatology," Late-Quaternary Environments of the United States, H.E. Wright, Jr. (ed.), Volume 1 of The Late Pleistocene, S.C. Porter (ed.), University of Minnesota Press, Minneapolis, MN.

Barraclough, J.T., Robertson, J.B. and Janzer, V.J., 1976, Hydrology of the Solid-waste Burial Ground, as Related to the Potential Migration of Radionuclides, Idaho National Engineering Laboratory, U.S. Geological Survey Open-File Report 76-471, 183 p.

Beiswenger, J.M., 1987, "Late Quaternary Vegetational History of Grays Lake, Idaho and the Ice Slough, Wyoming," PhD Thesis, University of Wyoming, Laramie, WY.

Beiswenger, J.M., 1991, "Late Quaternary Vegetational History of Grays Lake, Idaho," Ecological Monographs, 6, 2, p. 165-182.

Benson, L.V. and Currey, D.R., 1990, "Chronology of Expansion and Contraction of Four Great Basin Lake Systems During the Past 35,000 years," Paleogeography, Paleoclimatology, Paleoecology, 78, pp. 241-286.

Birkeland, P.W., 1984, Soils and Geomorphology, Oxford University Press, New York.

Blackwell, D.D., 1989, "Regional Implications of Heat Flow of the Snake River Plain, Northwestern United States," Tectonophysics, 164, p. 323-343.

Bright, R.C., 1966, "Pollen and Seed Stratigraphy of Swan Lake, Southeastern Idaho; It's Relation to Regional Vegetational History and to Lake Bonneville History," Tebiwa, 9, p. 1-47.

Bright, R.C. and Davis, O.K., 1982, "Quaternary Paleoecology of the Idaho National Engineering Laboratory, Snake River Plain, Idaho," American Midland Naturalist, 108, 1, p. 21-33. 
Broecker, W.S., and van Donk, J., 1970, "Insolation Changes, Ice Volumes, and the 018 Record in Deep Ocean Cores," Reviews of Geophysics and Space Physics, 8, p. 169-198.

Butler, B.R., 1969, "More Information on the Frozen Ground Features and Further Interpretation of the Small Mammal Sequence at the Wasden Site (Owl Cave), Bonneville County, Idaho," Tebiwa, 12, 1, p. 58-63.

Butler B.R., 1972, "The Holocene or Postglacial Ecological Crisis on the Eastern Snake River Plain," Tebiwa, 15, 1, p. 49-63.

Campbell, J.E. and Cranwell, R.M., 1988, "Performance Assessment of Radioactive-Waste Repositories," Science, 239, p. 1389-1392.

Cerling, T.E., Poreda, R. J., and Rathburn, S. L., 1994, "Cosmogenic 3He and $21 \mathrm{Ne}$ Age of the Big Lost River Flood, Snake River Plain, Idaho," Geology, 22, p. 227-230.

Champion, D.E., Lanphere, M.A, and Kuntz, M.A., 1988, "Evidence for a New Geomagnetic Reversal from Lava Flows in Idaho: Discussion of Short Polarity Reversals in the Brunhes and Late Matuyama Polarity Chrons," Journal of Geophysical Research, 93, p. 11,667-80.

Colman, S.M. and Pierce, K.L., 1981, Weathering Rinds on Andesitic and Basaltic Stones as a Quaternary Age Indicator, Western United States, U.S. Geological Survey Professional Paper 1210, 56 p.

Cranwell, R.M., Guzowski, R.V., Campbell, J.E., and Ortiz, N.R., 1982, Risk Methodology for Geologic Disposal of Radioactive Waste: Scenario Selection Procedure, NUREG/CR-1667, Sandia National Laboratory, Albuquerque, NM.

Dansgaard, W. et al., 1993, Nature, 364, p. 218-220.

Davis, O.K, 1984, "Multiple Thermal Maxima During the Holocene," Science, 225, p. 617-619.

Davis, O.K. and Sheppard, J.C., 1986, "Contrasting Climatic Histories for the Snake River Plain, Idaho, Resulting from Multiple Thermal Maxima," Quaternary Research, 26, 321-339.

Dechert, T.V., McDaniel, P.A., and Falen, A.L., 1993, Aggradational and Erosional History of the Radioactive Waste Management Complex at the Idaho National Engineering Laboratory, EGG-WM-11049.

Denton, G.H. and Porter, S.C., 1970, "Neoglaciation," Scientific American, 222, p. 101-110.

DOE, 1994, Performance Assessment Task Team Progress Report, DOE/LLW-157, Revision 1, May, 1994.

Evenson E.B., Cotter, J.F.P., and Clinch, J.M., 1982, "Glaciation of the Pioneer Mountains: A Proposed Model for Idaho," Cenezoic Geology of Idaho: Idaho Bureau of Mines and Geology Bulletin, 26, B. Bonnichsen and R.M. Breckenridge (eds.), p. 653-666. 
Forman, S.L. et al., 1993, "Timing of late Quaternary Glaciations in the Western United States Based on the Age of Loess on the Eastern Snake River Plain, Idaho," Quaternary Research, 30, p. 30-37.

Greeley, R., and King, J.S., 1977, Volcanism of the Eastern Snake River Plain, Idaho, NASA/CR-154621.

GRIP, (Greenland Ice-core Project Members), 1993, "Climate Instability During the Last Interglacial Period Recorded in the GRIP Ice Core," Nature, 364, p. 203-207.

Hackett, W.R., 1993, Potential impacts of selected magmatic processes at the Radioactive Waste Management Complex, Idaho National Engineering Laboratory, Engineering Design File No. RWMC-641, 9 p.

Hackett, W.R. and Smith, R.P., 1994, Volcanic Hazards of the Idaho National Engineering Laboratory and adjacent areas, Lockheed Martin Idaho Technologies Report INEL-94/0276, 31 p.

Hackett, W.R., Jackson, S.M., and Smith, R.P., 1994 in press, "Paleoseismology of Volcanic Environments," Techniques in Paleoseismology, J.P. McCalpin and others, eds.), Academic Press, New York, NY.

Hackett, W.R. and Smith, R.P., 1992, "Quaternary Volcanism, Tectonics, and Sedimentation in the Idaho National Engineering Laboratory Area," Field Guide to Geologic Excursions in Utah and Adjacent Areas of Nevada, Idaho, and Wyoming, J.R. Wilson (ed.), Utah Geological Survey Miscellaneous Publication 92-3, p. 1-18.

Henry, C., 1984, "Holocene Paleoecology of the Western Snake River Plain, Idaho," MS thesis, University of Michigan, Ann Arbor, MI.

Houghton, J.T., Jenkins, G.J., and Ephraums, J.J., 1990, Climate Change: The IPCC Scientific Assessment, Cambridge University Press, Cambridge.

Hubbell, J.M., Hull, L.C., Humphrey, T.G., Russell, B.F., Pittmann, J.R., and Cannon, K.M., 1985, Annual Progress Report: FY-1985 Subsurface Investigations Program at the Radioactive Waste Management Complex of the Idaho National Engineering Laboratory, DOE/ID-10136, December 1985, 44 pp.

Hubbell, J.M., Hull, L.C., Humphrey, T.G., Russell, B.F., Pittmann, J.R., and Fischer, P.R., 1987, Annual Progress Report: FY-1986 Subsurface Investigations Program at the Radioactive Waste Management Complex of the Idaho National Engineering Laboratory, DOE/ID-10153, January 1987,69 pp.

Hughes, J.D., 1993, "Analysis of Characteristics of Sedimentary Interbeds at the Radioactive Waste Management Complex, Idaho National Engineering Laboratory, Idaho," MS thesis, Geology Department, Idaho State University, Pocatello, ID, 74 p. 
Hunter, R.L., 1983, Preliminary Scenarios for the Release of Radioactive Waste from a Hypothetical Repository in Basalt of the Columbia Plateau, NUREG/CR-3353, Sandia National Laboratory, Albuquerque, NM.

Kerr, R.A., 1993, "Even Warm Climates Get the Shivers," Science, 261, p. 292.

Knoll, KM., 1977, Chronology of Alpine Glacier Stillstands East-central Lemhi Range, Idaho, Idaho State University Museum of Natural History, Pocatello, ID.

Kuntz, M.A., Spiker, E.C., Rubin M., Champion, D.E., and Lefebvre, R.H., 1986, "Radiocarbon Studies of Latest Pleistocene and Holocene Lava Flows of the Snake River Plain, Idaho: Data, Lessons, Interpretations," Quat. Res., 25, p. 163-176.

Kuntz, M. A. Champion, D.E., Lefebvre, R.H., and Covington, H.R., 1988, "Geologic Map of the Craters of the Moon, Kings Bowl, Wapi Lava Fields, and the Great Rift Volcanic Rift Zone, South-central Idaho," U.S. Geological Survey Misc. Invest. Series Map I-1632, scale 1:100,000.

Kuntz, M.A. et al., 1994, "Geologic Map of the Idaho National Engineering Laboratory and Adjoining Areas, Eastern Idaho," U.S. Geological Survey Miscellaneous Investigations Map I-2330, 1:100,000-scale.

Kuntz, M.A., Covington, H.R., and Schorr, L.J., 1992, "An Overview of Basaltic Volcanism of the Eastern Snake River Plain, Idaho," Regional Geology of Eastern Idaho and Western Wyoming: Geological Society of America Memoir, 179, P.K. Link, M.A. Kuntz, and L.B. Platt (eds.), p. 227-268.

Leeman, W.P., 1982, "Development of the Snake River Plain - Yellowstone Plateau Province Idaho and Wyoming: An Overview and Petrologic Model," Cenezoic Geology of Idaho, B. Bonnichsen and R.M. Breckenridge (eds.), Idaho Geological Survey Bulletin 26.

Lennstrom, H.A, 1985, "Holocene Vegetation History of the Eastern Snake River Plain: An Analysis of Seventeen Woodrat (Neotoma) Middens," MS thesis, University of Minnesota, St. Paul, MN, 167 p.

Lewis, G.C. and Fosberg, M.A., 1982, "Distribution and Character of Loess and Loess Soils in Southeastern Idaho," Cenezoic Geology of Idaho, B. Bonnichsen and R.M. Breckenridge (eds.), Idaho Geological Survey Bulletin 26.

Malde, H.E, 1991, "Quaternary Geology and Structural History of the Snake River Plain, Idaho and Oregon," in R.B. Morrison (ed.), Quaternary Nonglacial Geology; Conterminous U.S., Boulder, CO, Geological Society of America, The Geology of North America, V. K-2.

Martineau, R.C., Hoggan, D.H., Keck, K.N., and .Wood, T.R., 1990, Hydrologic Modeling Study of Potential Flooding at the Subsurface Disposal Area from a Hypothetical reach of Dike 2 at the Idaho National Engineering Laboratory, EGG-WM-9502, EG\&G Idaho, Inc. 
Mears, B. Jr., 1974, "The Evolution of the Rocky Mountain Glacial Model," Glacial Geomorphology, D.R. Coates (ed.), New York State University Press, p. 11-40.

Miller, S.J., 1994, "Taphonomy and Paleoecology of the Vertebrate Fauna, Owl Cave, the Wasden Site, Southeastern Idaho," Ph.D. thesis, Idaho State University, Pocatello, ID.

Morgan, L.A., 1992, "Stratigraphic Relations and Paleomagnetic and Geochemical Correlations of Ignimbrites of the Heise Volcanic Field, Eastern Snake River Plain, Eastern Idaho and Western Wyoming," Regional geology of Eastern Idaho and Western Wyoming: Geological Society of America Memoir, 179, P.K. Link et al. (eds.), p. 215-226.

Morrison, R.B., 1991, "Introduction," in R.B. Morrison (ed.), Quaternary Nonglacial Geology; Conterminous U.S., Boulder, CO, Geological Society of America, The Geology of North America, V. K-2.

Nace, R.L. et al, 1975, Generalized Geologic Framework of the National Reactor Testing Station, Idaho, United States Geological Survey Professional Paper 725-B.

Pelton, J.R., 1991, Analysis of Geodetic Leveling Data in the Vicinity of the Idaho National Engineering Laboratory, Engineering Design File NPR-MHTGR-0332.

Pierce, K.L. et al., 1982, Loess Deposits of Southeastern Idaho: Age and Correlation of the Upper Two Loess Units, B. Bonnichsen and R.M. Breckenridge (eds.), Cenezoic Geology of Idaho, Idaho Bureau of Mines and Geology, Bulletin 26.

Pierce, K.L. and Morgan, L.A., 1992, "The Track of the Yellowstone Hotspot: Volcanism, Faulting, and Uplift," Regional Geology of Eastern Idaho and Western Wyoming: Geological Society of America Memoir, 179, P.K. Link et al. (eds.), p. 1-54.

Pierce, K.L. and Scott, W.E., 1982, "Pleistocene Episodes of Alluvial-gravel Deposition, Southeastern Idaho," in B. Bonnichsen and R.M. Breckenridge (eds.), Cenezoic Geology of Idaho, Idaho Bureau of Mines and Geology, Bulletin 26.

Rathburn, S.L., 1989, "Pleistocene Glacial Outburst Flooding Along the Big Lost River, EastCentral Idaho," Prepublication Manuscript, University of Arizona, 41 p.

Rathburn, S.L., 1991, Quaternary Channel Changes and Paleoflooding Along the Big Lost River, Idaho National Engineering Laboratory, EGG-WM-9909.

Rathburn, S.L, 1993, "Pleistocene Cataclysmic Flooding Along the Big Lost River, East-Central Idaho," Geomorphology, 8, p. 305-319.

Reilinger, R.E. et al., 1976, "Recent Vertical Crustal Movements from Precise Leveling Data in Southwestern Montana, Western Yellowstone National Park and Snake River Plain," Journal of Geophysical Research, 82, 33, p. 5349-5359. 
Richmond, G.M., 1986, "Stratigraphy and Chronology of Glaciations in Yellowstone National Park," Quaternary Glaciations in the Northern Hemisphere, Pergamon Press, New York, NY, p. 83-98.

Rightmire, C.T. and Lewis, B.D., 1987, Hydrogeology and Geochemistry of the Unsaturated Zone, Radioactive Waste Management Complex, Idaho National Engineering Laboratory, Idaho, DOE/ID-22073.

Ringe, B.L., 1992, Archaeological Test Excavation of 10-BT-1230, EGG-CS-10268, EG\&G Idaho.

Rodgers, D.W., Hackett, W.R., and Ore, H.T., 1990, "Extension of the Yellowstone Plateau, Eastern Snake River Plain and Owyhee Plateau," Geology, 18, p. 1138-1141.

Schmidt, D.L. and Mackin, J.H, 1970, Quaternary Geology of Long and Bear Valleys, Westcentral Idaho, U.S. Geological Survey Bulletin 1131-A, 22 p.

Schumm, S.A. and Chorley, R.J., 1983, Geomorphic Controls on the Management of Nuclear Waste, NUREG/CR-3276, Colorado State University, Fort Collins, CO, 137 p.

Scott, W. E., 1982, "Surficial Geologic Map of the Eastern Snake River Plain and Adjacent Areas, 111 to $115^{\circ} \mathrm{W}$, Idaho and Wyoming," U.S. Geological Survey Miscellaneous Investigations Series map I-1372.

Smith, R.P., Hackett, W.R., and Rodgers, D.W., 1989, "Geological Aspects of Seismic Hazards Assessments at the INEL, Southeastern Idaho," Proceedings of the Second DOE Natural Hazards Mitigation Conference, Knoxville, TN, p. 282-289.

Steadman, D.W., Mead, J.I., Bright, R.C., and Force, C., in press, "Late Quaternary Plants and Animals from Rattlesnake Cave, Snake River Plain, Idaho, " manuscript submitted to the U.S. Department of Energy, Idaho Operations Office, Idaho Falls, 43 p.

Thelin, G.P. and Pike, R.J., 1991, "Landforms of the Conterminous United States - A Digital Shaded-relief Portrayal," U.S. Geological Survey Miscellaneous Investigations Series Map I-2206, with 16 p. text.

Thompson, R.S., 1991, "Pliocene Environments and Climates in the Western United States," Quaternary Science Review, 10, pg. 115-132.

Thompson, R.S., Whitlock, C., Bartlein, P.J., Harrison, S.P., and Spaulding, W.G., 1993, "Climatic Changes in the Western United States Since 18,000 Years Before Present," in Global Climates Since the Last Glacial Maximum, H.E. Wright Jr., J.E. Kutzbach, T. Webb II, W.F. Ruddiman, F.A. Street-Perrott, and P.J. Bartlein (eds.), University of Minnesota Press, Minneapolis, MN, pp. 468-513.

Volcanism Working Group, 1990, Assessment of Potential Volcanic Hazards for the New Production Reactor Site at the Idaho National Engineering Laboratory, EGG-NPR-10624, EG\&G Idaho, Inc., 98 p. 
Whitlock, C. and Bartlein, P.J., 1993, "Spatial Variation of Holocene Climatic Change in the Yellowstone Region," Quaternary Research, 39, p. 231-238.

Williams, P.L., 1961, "Glacial Geology of the Stanley Basin, Idaho," Bureau of Mines and Geology Pamphlet 123, 29 p.

Wong, I.G., Olig, S., Wright, D., Youngs, R., Silva, W., Stark, C., Smith, R.P., and Jackson, S.M., 1995, "Microzonation for earthquake ground shaking at the Idaho National Engineering Laboratory," Proceedings of the Sixth DOE Natural Phenomena Hazards Mitigation Conference, November, Denver, CO.

Woodward-Clyde Federal Services, 1993, "Site-Specific Probabilistic Seismic Hazard Analyses for the Idaho National Engineering Laboratory," unpublished subcontract report. 
Appendix A

Glossary of Terms 


\section{Appendix A}

\section{Glossary of Terms}

Aggradation--The buildup of the earth's surface by deposition.

Alluvium--Sediment deposited by flowing water, as in a river bed, a flood plain, a delta, or a fan.

Altithermal--A climatic period corresponding to the Archaic cultural periods from 7,500 to 3,500 BP. The Altithermal climate was an extended warming period with apparent long droughts resulting from the shift of major latitudinal wind patterns.

Anthropogenic--Pertaining to the effects of human activity.

Archaeology--The scientific study of the physical evidence of past human societies. Archaeology's initial objective is the construction of descriptive cultural chronology, its intermediate objective is the description of past lifeways, and its ultimate objective involves discovery of the processes that underlie and condition human behavior.

B.P.--Before present (i.e., before 1950 A.D.)

Basalt--A dark-colored igneous rock of volcanic origin.

Barchan dunes--An isolated crescent-shaped sand dune lying transverse to the direction of the prevailing wind, with a gently sloping convex side facing the wind, wings, or horns of the crescent pointing downwind, and a steep concave leeward slope inside the horns.

Braided stream--A stream that divides into or follows a tangled network of small interlacing stream channels.

Caliche--A term applied to a buff or white calcareous material of secondary accumulation, commonly found in layers on or near the surface of stony soils of arid and semiarid regions, but also occurring as subsoil deposit in subhumid climates. It may occur as a thin porous friable horizon within the soil, but more commonly, it is several centimeters to a meter or more in thickness, impermeable, and strongly indurated; the cementing material is essentially calcium carbonate, but it may include magnesium carbonate, silica, or gypsum.

Carapace--The solidified surface of a body of molten magma.

Cenozoic--The latest of the four geologic eras, encompassing the last 65 million years and characterized by the evolution of familiar and modern animals.

Chronology--The temporal ordering of data. Chronologies or time charts can involve absolute dating (e.g., thermoluminescence dating, carbon-14 dating), or relative dating (e.g., stratigraphy, obsidian hydration). 
Contact--A plane or irregular surface between two types or ages of rock.

Cosmogenic--Produced by the action of cosmic radiation.

Cultural Resources--Prehistoric or historic sites, structures, districts, landscapes, and objects of some importance to a culture or community for scientific, traditional, religious, or other reasons. A broad general term meaning any cultural property or traditional lifeway value.

Deformation-A general term for the process of folding, faulting, shearing, compression, or . extension of the rocks as a result of various earth forces.

Deranged-A disordered drainage pattern caused by a lack of structural or bedrock control.

Diamict-A nonsorted or poorly sorted, noncalcareous, terrigenous sedimentary deposit that contains a wide range of particle sizes.

Displacement (ecological)--A shift in the position of ecosystem boundaries.

Edaphic-A term referring to soil or substrate conditions as ecological factors.

Effusion--The emission of relatively fluid lava onto the Earth's surface.

Entrainment--The process of picking up and carrying along, as the collecting and movement of sediment by currents.

Eolian-Erosion, transportation, and deposition by the wind.

Extrusion--The emission of relatively viscous lava onto the Earth's surface.

Fauna-A Latin term that refers to animals, as opposed to flora, which refers to plants.

Flora-A Latin term that refers to plants, as opposed to fauna, which refers to animals.

Fluvial deposition--Deposition of sediment transported by, suspended in, or laid down by a stream.

Folsom Points--A spear point characterized by a single, well-made flute on each side and fine pressure flaking. Folsom points were made from about 11,000-12,000 BP and are generally found in western North America, often in association with extinct bison.

Fossil--Any evidence of past life, including plants (pollen, seeds, leaves), and animals (vertebrates and invertebrates), and traces (tracks, burrows).

g-A measurement of ground motion expressed in terms of gravity.

Geochronometry--Measurement of geologic time by absolute and relative age dating techniques.

Geodetic surveying--Surveying that takes into account the shape and size of the Earth, and corrections are made for earth curvature. 
Geomorphology--The study of the classification, description, nature, origin, and development of present landforms and their relationships to underlying structures, and of the history of geologic changes as recorded by these surface features.

Glacial outburst flood--A sudden, often annual, release of meltwater from a glacier or glacierdammed lake, sometimes resulting in a catastrophic flood, formed by melting of a drainage channel or buoyant lifting of ice by water or by subglacial volcanic activity.

Holocene--An epoch of the Quaternary period from the end of the Pleistocene, approximately $10,000 \mathrm{BP}$ to the present time.

Horizon--See soil horizon.

Hotspot--A volcanic center that is thought to be the surface expression of a persistent rising plume of hot mantle material.

Hypsithermal--Same as Altithermal.

Illuvial horizon--A soil horizon to which material has been added by the process of illuviation in which soluble or suspended material is transported from an upper horizon by groundwater percolation (eluviation).

Illuviation--The accumulation, in a lower soil horizon, of soluble or suspended material that was transported from an upper horizon by the process of downward movement by groundwater percolation.

Infiltration--The flow of a fluid into a solid substance through pores or small openings; specifically the movement of water into soil or porous rock.

Insolation--The combined direct solar and sky radiation reaching the earth.

Intermittent stream--A stream or reach of a stream that flows only at certain times of the year, as when it receives water from springs or from some surface source.

Lacustrine--Pertaining to or produced by a lake or lakes.

Lag--A residual accumulation of coarse rock fragments remaining on a surface after the finer material has been transported away by wind or water.

Lake Terreton--An extensive shallow inland lake that covered a large portion of the north-eastern Snake River Plain during the Pleistocene.

Lithosphere--The solid portion of the Earth. In plate tectonics, a layer of strength relative to the underlying asthenosphere, including the crust and part of the upper mantle.

Loess--Wind deposited sediment predominately of silt size with subordinate grain sizes ranging from clay to fine sand. 
Longitudinal dunes--A long, narrow sand dune, usually symmetrical in cross profile, oriented parallel with the direction of the prevailing wind; it is wider and steeper on the windward side but tapers to a point on the leeward side.

Magmatic processes--Related to the existence or activity of molten rock.

Mass movement--A unit movement of a portion of the land surface, specifically the transfer of material down a slope by gravity.

Midden--An accumulation of debris by biological agents such as packrats or humans. May include plant matter, bone, and shell fragments. For prehistoric sites, a layer of soil stained to a dark color by the decomposition of organic refuse such as food bones, fragments of stone tools, charcoal, pieces of pottery, or other discarded materials. For historic sites, a similar layer of soil, but with appropriate historic material remains, often in a much thinner deposit.

Montane--Of, pertaining to, or inhabiting cool upland slopes below the timber line, characterized by a dominance of evergreen trees.

Moraine-A mound, ridge, or other distinct accumulation of unsorted, unstratified glacial drift, predominantly till, deposited chiefly by direct action of glacier ice, in a variety of topographic landforms that are independent of control by the surface on which the drift lies.

Morphology--The shape of the earth's surface; [geomorph] a surface, either erosional or depositional, that is recognized by its topographic character.

Neoglacial--The readvance of glaciers during a Little Ice Age interval of the late Holocene.

Normal Fault--A fault in which the hanging wall appears to have moved downward relative to the footwall.

Paleomagnetism--The study of natural remnant magnetization in order to determine the intensity and direction of the Earth's magnetic field in the geologic past.

Paleosol--A buried soil horizon of the geologic past.

Palynology--The study of past vegetation and climate through microscopic and radiocarbon analyses of pollen recovered from sediments or middens.

Parabolic dunes--A sand dune with a long, scoop-shaped form, convex in the downwind direction so that its horns point upwind; whose ground plan, when perfectly developed, approximates the form of a parabola.

Pedestal (plants)--A relatively slender column of soil stabilized by vegetation (usually bunchgrasses) and caused by erosion of the surrounding unstabilized soils.

Pedogenic--Pertaining to soil formation. 
Playa--A dry, flat area at the lowest part of an undrained desert basin, underlain by stratified clay, silt, or sand, and commonly by soluble salts, often with sparse, salt-tolerant vegetation.

Physiography--A description of the surface features of the Earth, as bodies of air, water, and land.

Pleistocene--A geologic epoch, usually thought of as the Ice Age, which began about 1.6 million years ago and ended with the melting of the large continental glaciers, creating the modern climatic pattern about 11,500 years ago.

Pluvial (climate)--A climate characterized by relatively high precipitation, or the time interval during which such a climate prevailed.

Pluvial (geomorphology)-A geologic episode, process, deposit, or feature resulting from the action or effects of rain, e.g., pluvial lakes such as Lake Terreton or Lake Bonneville.

Pyroclastic--Pertaining to rock fragments formed by volcanic explosion or aerial expulsion from a volcanic vent.

Quaternary--The most recent geologic period, dating from approximately 2 million years ago to the present. The Quaternary includes the Pleistocene and Holocene Epochs.

Radiocarbon Dating--A physicochemical method of estimating the length of time since the death of an organism. A process that provides absolute dates by counting the radioactive decay of carbon in the remains of once-living plants and animals (i.e., charcoal, wood, bone, shell).

Rhyolite--A group of extrusive igneous rocks, typically porphyritic and commonly exhibiting flow texture, with phenocrysts of quartz and alkali feldspar in a glassy to cryptocrystalline groundmass.

Rill erosion--The development of numerous, minute, closely spaced channels resulting from the uneven removal of surface soil by running water that is concentrated in streamlets of sufficient discharge and velocity to generate cutting power.

Sheet flow--Overland flow or downslope movement of water in a thin, continuous film over relatively smooth soil or rock surfaces and not concentrated in channels larger than rills.

Silicic--Said of a silica-rich igneous rock or magma.

Sinks--Low area on the Northeastern Snake River Plain near the foothills of the Lemhi and Lost River Ranges where the Big Lost River, the Little Lost River, and Birch Creek cease all overland flow and infiltrate through porous basalt bedrock to the Snake River Plain Aquifer.

Slopewash--Soil and rock material that is or has been transported down a slope by mass wasting assisted by running water not confined to channels.

Snake River Plain--Broad arcuate depression extending more than $500 \mathrm{~km}$ across southern Idaho. It is marked by basaltic lava flows, prominent volcanic buttes, alluvial and lacustrine features, 
and deposits of eolian silts and sands within a semiarid sagebrush-steppe vegetation community.

Soil creep--The gradual, steady downhill movement of soil and loose rock material on a slope that may be very gentle but is usually steep.

Soil horizon-A layer of a soil that can be distinguished from adjacent layers by characteristic physical properties such as structure, color, or texture, or by chemical composition.

Stratigraphy--The arrangement of strata with respect to geographic position and chronologic order.

Subsidence--The sudden sinking or gradual downward settling of the Earth's surface with little or no horizontal motion. Subsidence may be caused by natural geologic processes, such as solution, thawing, compaction, slow crustal warping, or withdrawal of fluid lava from beneath a solid crust.

Substrate--Any layer beneath the surface A and B soil horizons.

Tectonics--The assemblage of regional structural or deformational features, a study of their mutual relations, origin, and historical evolution.

Tephra cones--Built of pyroclastic volcanic material.

Terrestrial--Pertaining to the earth; a sedimentary deposit laid down on land above tidal reach.

Thermoluminescence dating--A method of dating applicable to materials that have once been heated. A fraction of the energy released by decay of long-lived radioactive nuclides is stored as trapped electrons, and this energy is released as light upon heating. The age of a sample can be determined if the natural thermoluminescence is measured, the thermoluminescence induced by a known radiation dose is measured, and the radiation dose received by the sample per unit time in the past is measured.

Till-Unsorted and unstratified drift, generally unconsolidated, deposited directly by and underneath a glacier without subsequent reworking by meltwater, and consisting of a heterogeneous mixture of clay, silt, sand, gravel, and boulders ranging widely in size and shape.

Unconformity--A break or gap in the stratigraphic record, as a result of erosion or a period of nondeposition, where a rock or soil unit is overlain by another that is not next in stratigraphic succession.

Windgap--A former water gap, now abandoned by the stream that formed it; a pass that is not occupied by a stream.

Xeric--A habitat characterized by a low or inadequate supply of moisture.

Xeric Maximum--Coincides with the Altithermal period of the Holocene Epoch. 